\title{
Article
}

\section{Variable Molecular Weight Polymer Nanoparticles for Detection and Hyperthermia-Induced Chemotherapy of Colorectal Cancer}

\author{
Santu Sarkar and Nicole Levi *
}

check for updates

Citation: Sarkar, S.; Levi, N. Variable Molecular Weight Polymer

Nanoparticles for Detection and Hyperthermia-Induced Chemotherapy of Colorectal Cancer. Cancers 2021, 13, 4472. https:// doi.org/10.3390/cancers13174472

Academic Editor: Tatjana Paunesku

Received: 10 July 2021

Accepted: 31 August 2021

Published: 5 September 2021

Publisher's Note: MDPI stays neutral with regard to jurisdictional claims in published maps and institutional affiliations.

Copyright: (c) 2021 by the authors. Licensee MDPI, Basel, Switzerland. This article is an open access article distributed under the terms and conditions of the Creative Commons Attribution (CC BY) license (https:// creativecommons.org/licenses/by/ $4.0 /)$.
Department of Plastic and Reconstructive Surgery, Wake Forest University School of Medicine, Winston-Salem, NC 27157, USA; santchem83@gmail.com

* Correspondence: nlevi@wakehealth.edu

Simple Summary: The purpose of this work was to evaluate the development of polymer-based nanoparticles that can both generate heat and be used for fluorescence detection. The nanoparticles were used against luminescent colorectal cancer cells that were either sensitive or resistant to the chemotherapy drug, oxaliplatin. The fluorescence of the nanoparticles indicates that they are internalized within the cells for heat generation. Mild heating makes oxaliplatin-resistant cancer cells responsive to chemotherapy, and the nanoparticle-induced hyperthermia causes cell death in a few minutes, compared to classical bulk heating, which takes a few hours. Changes in the luminescence of the cancer cells can be used to determine the thermal dose induced by the nanoparticles, which may be correlated with the cell viability and therapeutic response.

Abstract: Oxaliplatin plays a significant role as a chemotherapeutic agent for the treatment of colorectal cancer (CRC); however, oxaliplatin-resistant phenotypes make further treatment challenging. Here, we have demonstrated that rapid (60 s) hyperthermia $\left(42{ }^{\circ} \mathrm{C}\right)$, generated by the near-infrared stimulation of variable molecular weight nanoparticles (VMWNPs), increases the effectiveness of oxaliplatin in the oxaliplatin-resistant CRC cells. VMWNP-induced hyperthermia resulted in a higher cell death in comparison to cells exposed to chemotherapy at $42{ }^{\circ} \mathrm{C}$ for $2 \mathrm{~h}$. Fluorescence from VMWNPs was observed inside cells, which allows for the detection of CRC. The work further demonstrates that the intracellular thermal dose can be determined using cell luminescence and correlated with the cell viability and response to VMWNP-induced chemotherapy. Mild heating makes oxaliplatin-resistant cancer cells responsive to chemotherapy, and the VMWNPs-induced hyperthermia can induce cell death in a few minutes, compared to classical bulk heating. The results presented here lay the foundation for photothermal polymer nanoparticles to be used for cell ablation and augmenting chemotherapy in drug-resistant colorectal cancer cells.

Keywords: hyperthermia; nanoparticles; chemotherapy; colorectal cancer; fluorescent detection

\section{Introduction}

Colorectal cancer (CRC) is the fourth leading cause of cancer-related deaths, with few available treatment options [1-3]. Recent clinical studies showed that hyperthermia $\left(39-42^{\circ} \mathrm{C}\right.$ ) is an effective adjuvant therapeutic technique along with radiotherapy and/or chemotherapy, and that specifically $42{ }^{\circ} \mathrm{C}$ is routinely used clinically with intraperitoneal chemotherapy for the treatment of CRC [4-9]. Among the available chemotherapeutic drugs, oxaliplatin is a cornerstone for the treatment of CRC. One of the major disadvantages is that, due to the intermittent exposures of oxaliplatin, the cells become chemo-resistant, complicating treatment [10-12]. Hyperthermia increases the drug uptake by affecting cell membranes and producing drug-induced DNA damage, leading to enhanced tumor cell death [13-16]. It has been demonstrated that hyperthermia is synergistic with oxaliplatin for treating CRC $[9,17,18]$. In order to improve the precision of the technique, instead of using a bulk carrier fluid along with a heat exchanger in the traditional hyperthermia 
delivery, photothermal nanoparticles can be used to deliver more specific and effective hyperthermia.

Photothermal nanoparticles (NPs) that absorb light and generate heat have been extensively studied for both cancer cell ablation and mild hyperthermia. The most common photothermal agents are metallic; however, recent developments in the field of semiconducting polymers have instigated their evaluation as photothermal nanoparticles [19-27]. Recently, our team developed variable molecular weight nanoparticles (VMWNPs) produced from the oligomer and high MW segments of a single polymer, poly[4,4-bis(2ethylhexyl)-cyclopenta[2,1-b;3,4-b']-dithiophene-2,6-diyl-alt-2,1,3- benzoselenadiazole-4,7diyl] (PCPDTBSe), and have demonstrated that they are a promising photothermal agent for the ablation of breast cancer [28]. VMWNPs generated heat upon $800 \mathrm{~nm}$ laser irradiation and produced fluorescence emission at $825 \mathrm{~nm}$ upon excitation with $550 \mathrm{~nm}$. As shown in Scheme 1a, the facile synthesis of VMWNPs occurs using a nanoprecipitation method. The high molecular weight (HMW) fraction is capable of heat generation through electronhole recombination, whereas the oligomer fraction is capable of fluorescence emission, as shown in Scheme 1b. Therefore, VMWNPs can be used to detect CRC through fluorescence imaging, as well as provide hyperthermia delivery. Here, we have explored the synergistic effect of oxaliplatin and hyperthermia generated by the photothermal VMWNPs for augmenting oxaliplatin in sensitive and resistant CRC cells.

(a)

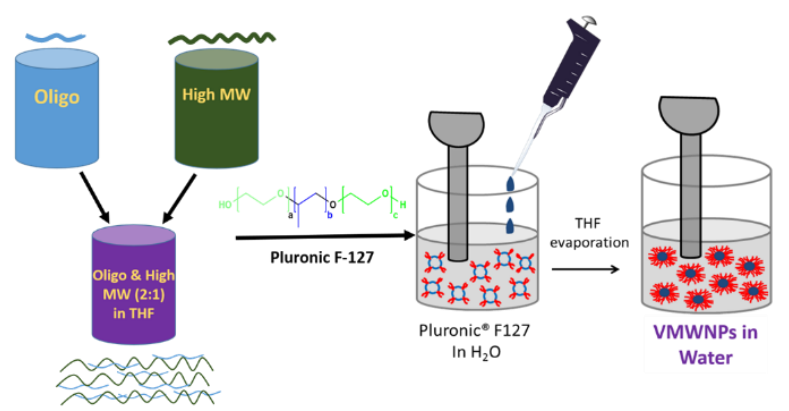

(b)

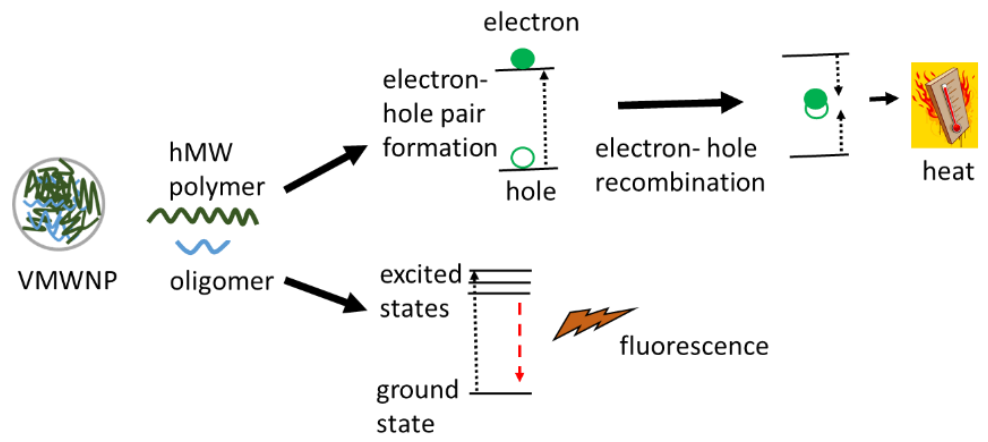

Scheme 1. (a) Ultrasonic preparation of VMWNPs. (b) Fluorescence and electron-hole pair formation/recombination when VMWNPs are stimulated with light.

\section{Materials and Methods}

\subsection{Cells and Materials}

CT-26 WT-Fluc-Neo, mouse CRC cells were purchased from Imanis Life Sciences. HT-29 and RKO human CRC cells were purchased from American Type Culture Collection. We previously developed oxaliplatin-resistant (OxR) cells for comparison to parental (oxaliplatin-sensitive (OxS) cells, as explained by McCarthy, et al. [29]. Dulbecco's Modified Eagle Medium (DMEM) supplemented with penicillin and streptomycin, L-glutamine, $400 \mu \mathrm{g} / \mathrm{mL}$ G418 and with or without $10 \%$ Fetal Bovine Serum (FBS) was obtained from Gibco. McCoy's Medium with penicillin and streptomycin, L-glutamine and with and without 10\% FBS, was purchased from Gibco. Oxaliplatin, 1,3-diphenylisobenzofuran (DPBF) and Pluronic F-127 were purchased from Sigma-Aldrich. 4',6-diamidino-2-phenylindole 
(DAPI) and Alexa Fluor ${ }^{\circledR} 488$ were purchased from Abcam. Tetrahydrofuran (THF) was purchased from Acros Organics. CellTiter $96{ }^{\circledR}$ AQueous One Solution Cell Proliferation Assay (MTS) was obtained from Promega. Phosphate-buffered saline (PBS; $1 \times$ ) buffer with $\mathrm{pH}$ 7.4 was prepared and sterilized before use. 4,7-Dibromo-2,1,3-benzoselenadiazole and 4,4Bis(2-ethyl-hexyl)-4H-cyclopenta[2,1-b:3,4- $\mathrm{b}^{\prime}$ ]dithiophene were obtained from TCI America.

PCPDTBSe was synthesized following published procedures [30]. Briefly, 4,4-Bis(2ethylhexyl)-2,6-bis(trimethylstannyl)-4H-cyclopenta [2,1-b;3,4-b']-dithiophene (1.5 mmol) and 4,7-dibromo-2,1,3-benzoselenadiazole $(1 \mathrm{mmol})$ were combined in anhydrous toluene followed by the addition of $\mathrm{Pd}\left(\mathrm{PPh}_{3}\right)_{4}(5 \mathrm{~mol} \%)$ and stirred at $110{ }^{\circ} \mathrm{C}$ for $24 \mathrm{~h}$ to obtain a mixture of oligomer, low molecular weight (MW) and high MW polymer fractions. The polymer fractions were separated by Soxhlet extraction using methanol $(3 \mathrm{~h})$, hexane $(6 \mathrm{~h})$ and chloroform $(6 \mathrm{~h})$. The methanol, hexane and chloroform fractions were evaporated to collect oligomer, low MW and high MW polymer fractions, respectively.

Absorbance spectra of the oligomer and high MW PCPDTBSe in THF were recorded using a Mettler Toledo UV-Vis spectrophotometer. Fluorescence spectra of the polymer fractions were obtained using a TECAN M200 Infinite plate reader with $\lambda_{\mathrm{ex}}=550 \mathrm{~nm}$.

\subsection{Preparation and Characterization of VMWNPs}

VMWNPs were prepared by nanoprecipitation following the methods described by Sarkar et al. [28]. Briefly, $1 \mathrm{mg}$ of the high MW (HMW) and $2 \mathrm{mg}$ of the oligomer PCPDTBSe were mixed in $2 \mathrm{~mL}$ THF and added to an $8 \mathrm{~mL}$ aqueous solution of Pluronic F-127 under horn sonication ( $20 \%$ amplitude, $110 \mathrm{~s}$ ). Similar techniques were used to develop nanoparticles composed of only the oligomer or only the HMW fractions. THF was evaporated and the particles were sterilized by autoclaving prior to being centrifuged at $7500 \mathrm{rpm}$ for $30 \mathrm{~min}$ to pellet large NPs. The supernatant was centrifuged at 14,000 rpm for $10 \mathrm{~h}$ to collect small nanoparticles, which were used for the experimental studies.

\subsection{Heating Methods}

A $300 \mu \mathrm{L}$ solution of VMWNPs in cell culture media was irradiated with an $800 \mathrm{~nm}$ laser (Cube TM continuous-wave diode laser from Summus Medical Laser, Inc., Franklin, TN, USA ( 1 or $3 \mathrm{~W}$, beam diameter-1 cm)). A Fluke 714 thermometer and a type k 80Pk-1 bead probe wire thermocouple were used to measure the temperature of the solutions immediately before and after laser application. It was found that $1 \mathrm{~W}$ laser stimulation of VMWNPs for $60 \mathrm{~s}$ generated $42{ }^{\circ} \mathrm{C}$ for hyperthermia, and these parameters were used to augment chemotherapy. Photothermal ablation $\left(\mathrm{T}>45^{\circ} \mathrm{C}\right)$ was accomplished using either longer time with $1 \mathrm{~W}$, or else $3 \mathrm{~W}$ of laser power. A fiber optic thermocouple (Qualitrol Neoptix ${ }^{\circledR}$ and Nomad thermometer, Fairport, NY, USA) was alternatively used to measure continuous temperature increases in VMWNPs solutions over time.

\subsection{VMWNPs Cytotoxicity}

To evaluate VMWNPs' cytotoxicity to the OxS and OxR CT-26, HT-29 and RKO cells, they were individually plated at 5000 cells/well in 96 well plates and cultured for $24 \mathrm{~h}$. Two hundred microliters of VMWNPs solution with varying concentrations $(0,25,50,100,250$ and $500 \mu \mathrm{g} / \mathrm{mL}$ ) were added to triplicate wells and incubated for $24 \mathrm{~h}$ at $37^{\circ} \mathrm{C}$. Cells with no treatment were used as controls. Nanoparticle solutions were removed after $24 \mathrm{~h}$, cells were washed with PBS and viability was quantified using Promega's Cell Titer 96 AQueous assay kit.

\subsection{Singlet Oxygen Measurements}

DPBF was used to quantify generation of singlet oxygen upon laser irradiation. A $1 \mathrm{mg} / \mathrm{mL}$ DPBF solution in methanol was prepared and stored in dark. Absorbance $(418 \mathrm{~nm})$ of a $65 \mu \mathrm{g} / \mathrm{mL}$ DPBF solution in water was checked before and after three consecutive laser irradiation stimulation periods $(800 \mathrm{~nm}, 1 \mathrm{~W}, 60 \mathrm{~s})$ using a TECAN 
M200 Infinite plate reader before and after three consecutive laser treatments. Absorbance of DPBF solutions was also measured for samples without laser stimulation. Similar experiments were conducted with solutions containing $25 \mu \mathrm{g} / \mathrm{mL}$ VMWNPs, oligomeric or HMW nanoparticles and $65 \mu \mathrm{g} / \mathrm{mL}$ DPBF.

\subsection{Intracellular Concentration of VMWNPS}

To quantify intracellular concentration of VMWNPs, first a calibration curve was developed. The absorbance of $300 \mu \mathrm{L}$ of $0,25,50,100,250$ and $500 \mu \mathrm{g} / \mathrm{mL}$ VMWNPs in media with and without serum was measured at $760 \mathrm{~nm}$. Then, $\mathrm{OxS}$ and OxR cells were plated at 20,000 cells/well in FBS containing media in a 48-well plate and cultured for $24 \mathrm{~h}$. The media was aspirated and $300 \mu \mathrm{L}$ of varying concentrations $(0,25,50,100,250$ and $500 \mu \mathrm{g} / \mathrm{mL}$ ) of VMWNPs in FBS-containing media were added in triplicate. After $24 \mathrm{~h}$ of incubation, the nanoparticle solutions were removed and estimated by recording their absorbance at $760 \mathrm{~nm}$. Intracellular nanoparticle uptake was quantified by subtracting the NP concentration of the supernatant from the total concentration of NPs added. The same technique was also applied to cells that had been previously starved of serum by culturing in FBS-free media.

\subsection{Visualization of $V M W N P S$}

OxS and OxR CT-26 CRC cells were plated onto collagen-coated cover slips and incubated for $24 \mathrm{~h}$ with 0 or $100 \mu \mathrm{g} / \mathrm{mL}$ of VMWNPs in either FBS-free media. Following incubation, VMWNPs solutions were removed and cells were washed twice with cold PBS, fixed with $4 \%$ paraformaldehyde and then stained with Alexa-fluor-488 and 4',6-diamidino-2-phenylimdole (DAPI). An Olympus FV1200 SPECTRAL Laser scanning Confocal Microscope (Olympus IX83 inverted platform) was used to collect images of the cells and VMWNPs. To visualize the fluorescence from VMWNPs in vivo, a freshly euthanized female Balb/C mouse was intraperitoneally injected with $100 \mu \mathrm{L}$ or a $250 \mu \mathrm{g} / \mathrm{mL}$ VMWNPs solution and imaged using a Perkin Elmer Caliper in vivo imaging system (IVIS). Lamp excitation of $465 \mathrm{~nm}$ was used and the indocyanine green (ICG) filter was used to capture emitted light above $695 \mathrm{~nm}$.

\subsection{In Vitro Photothermal Effect of VMWNPS}

OxS and OxR CT-26 cells were used to evaluate the effect of intracellular VMWNPs on inducing cell death by photothermal ablation. The cells were plated at 10,000 cells/well in a 48-well plate in FBS-free media and cultured $24 \mathrm{~h}$. They were then incubated with $250 \mu \mathrm{g} / \mathrm{mL}$ of VMWNPs in FBS-free media for $24 \mathrm{~h}$, following washing to remove noninternalized VMWNPs, and exposed to $3 \mathrm{~W}$ of $800 \mathrm{~nm}$ light for 120, 180, 240 or $300 \mathrm{~s}$. Following photothermal treatment, cells were washed and incubated for $24 \mathrm{~h}$ before cell viability was quantified using Promega's Cell Titer 96 AQueous assay kit.

To evaluate the effect of extracellular VMWNP-induced photothermal ablation, OxS and OxR CT-26, HT-29 and RKO CRC cells were seeded at 20,000 cells /well in a 48-well plate and cultured for $24 \mathrm{~h}$. VMWNPs solutions $(0,25,50$ and $100 \mu \mathrm{g} / \mathrm{mL})$ were added to triplicate wells and incubated for $20 \mathrm{~min}$ at $37^{\circ} \mathrm{C}$ immediately prior to laser exposure. Plates were maintained at $37^{\circ} \mathrm{C}$ during laser exposure by placing them on a heat block, during which they were stimulated with $800 \mathrm{~nm}$ laser $(1 \mathrm{~W})$ for $60 \mathrm{~s}$ and $120 \mathrm{~s}$, respectively. Cells were incubated for $24 \mathrm{~h}$ and viability was quantified using Promega's Cell Titer $96 \mathrm{AQ}_{\text {ueous }}$ assay kit.

\subsection{Luminescent Monitoring of Thermal Dose Following VMWNPs-Induced Photothermal Ablation}

Thermal dose was determined by loss of intracellular luminescence following photothermal treatment. OxS and OxR CT-26 WT-Fluc-Neo CRC cells, which are luminescent, were seeded at 20,000 cells / well in 48-well plates and cultured for $24 \mathrm{~h}$. VMWNPs solutions $(0,25,50$ and $100 \mu \mathrm{g} / \mathrm{mL})$ were added to the cells in triplicate and incubated for $20 \mathrm{~min}$ at $37^{\circ} \mathrm{C}$ immediately prior to laser exposure. Cells were then stimulated with $800 \mathrm{~nm}$ laser 
$(1 \mathrm{~W})$ for $60 \mathrm{~s}$ and $120 \mathrm{~s}$, during which they were kept on a heat block set at $37^{\circ} \mathrm{C}$. Immediately after laser exposures, the treatment solutions were removed and cells were washed with PBS. Three hundred microliters of $150 \mu \mathrm{g} / \mathrm{mL}$ luciferase solution in DMEM media was added to each well and the plates were incubated at $37^{\circ} \mathrm{C}$ for $10 \mathrm{~min}$. Luminescence was measured using a FilterMax F5 Multi-Mode Microplate Reader (1000 ms integration time), and luminescence intensities were normalized to the relative luminescence at $37{ }^{\circ} \mathrm{C}$. Percentage loss of luminescence was calculated for each concentration of VMWNPs. Thermal dose was correlated to the loss of luminescence using CEM43 $=\int_{0}^{t} R^{(43-T)} d t(\min )$ to calculate cumulative equivalent minutes at $43{ }^{\circ} \mathrm{C}$ (CEM43). Here, $\mathrm{t}$ is time in minutes, $\mathrm{R}$ is a correction for the number of minutes required to achieve an isoeffect for each degree step away from $43{ }^{\circ} \mathrm{C}\left(\mathrm{R}=0.25\right.$ when $\mathrm{T}<43{ }^{\circ} \mathrm{C}$ and $\mathrm{R}=0.5$ when $\left.\mathrm{T}>43^{\circ} \mathrm{C}\right)$ and $\mathrm{T}$ is the temperature $[14,29,31,32]$. Calculated CEM43 at respective temperatures was then compared to CEM43 determined using the luminescence changes following laser stimulation of cells with VMWNPs.

\subsection{Photothermal Chemotherapy}

OxS and OxR cell lines were plated at 20,000 cells/well in 48-well plates and cultured for $24 \mathrm{~h}$. To evaluate the benefits of hyperthermia on oxaliplatin effectiveness, triplicates of cells were treated with concentrations of oxaliplatin $(5,25,100$ and $300 \mu \mathrm{M})$ in two different plates held at $37^{\circ} \mathrm{C}$ or $42^{\circ} \mathrm{C}$ for two hours. After oxaliplatin exposure, cells were washed with PBS, incubated for $48 \mathrm{~h}$ and cell viability was quantified using Promega's Cell Titer 96 $\mathrm{AQ}$ ueous assay kit.

Oxaliplatin efficiency against OxS and OxR cells was also assessed in the presence of VMWNPs, laser and NPs + laser (to generate mild hyperthermia at $42{ }^{\circ} \mathrm{C}$ ). Cells were seeded at 20,000 cells/well in 48-well plates and treated with 0, 5, 25, 100 and $300 \mu \mathrm{M}$ oxaliplatin in triplicate, in the independent presence of $25 \mu \mathrm{g} / \mathrm{mL}$ VMWNPs, laser $(800 \mathrm{~nm}$, $1 \mathrm{~W}, 60 \mathrm{~s}$ ) or NPs + laser. During the two hours of oxaliplatin exposure, three laser treatments were applied for each of the 'laser' and 'NPs + laser' treatment groups for a total of three $60 \mathrm{~s}$ intervals, with a $20 \mathrm{~min}$ normothermic recovery time. The rationale for applying three laser applications was to use the rapid heating from the NPs to aid in cell membrane permeabilization for oxaliplatin transport into cells and then return to normothermia for drug retention. Plates were maintained at $37^{\circ} \mathrm{C}$ during laser exposure by placing them on a heat block. After two hours, treatment solutions were aspirated and cells were washed with PBS, followed by addition of $300 \mu \mathrm{L}$ of media to each well. After $48 \mathrm{~h}$ of incubation, cell viability was quantified using Promega's Cell Titer 96 AQueous assay kit.

\section{Results}

\subsection{Preparation and Characterization of PCPDTBSe NPS and VMWNPS}

PCPDTBSe was synthesized through Stille coupling following reported literature procedures and characterized (Figure 1a) [33]. The different molecular weight fractions of PCPDTBSe showed that the oligomer NPs had a distinct absorption at $550 \mathrm{~nm}$, whereas the high MW fraction had an absorption maximum at $760 \mathrm{~nm}$ (Figure 1b). The oligomeric NPs showed a near-infrared fluorescence, with the peak maxima at $750 \mathrm{~nm}\left(\lambda_{\text {ex }}=550 \mathrm{~nm}\right)$, but the high MW fraction had a minimal fluorescence (Figure 1c). VMWNPs were prepared from the oligomer and high MW fraction using a nanoprecipitation method (Scheme 1a). The oligomer fluorescence emission was quenched due to the spectral overlap of the absorbance spectrum of the high MW PCPDTBSe and emission spectrum of the oligomer (Figure 1c). Quantum yield (QY) is a useful measurement to gauge the fluorescence of nanoparticles, and we have previously found the QY of oligomeric NPs to be 0.27 and VMWNPs to be 0.077 , which, although low in value, allows for fluorescence detection in vitro [28]. The average hydrodynamic diameter of VMWNPs was determined to be $80 \mathrm{~nm}$ (Figure 1d). The zeta potential of the nanoparticles was $-5.27 \mathrm{mV}$ (Supplementary Figure S1), and the particles were stable in water and serum-containing media. VMWNPs depicted an increase in temperature with increasing concentrations of VMWNPs 
(Figure 1e). A $42{ }^{\circ} \mathrm{C}$ elevation in temperature was observed by the laser irradiation of $100 \mu \mathrm{g} / \mathrm{mL}$ nanoparticles. To generate photothermal hyperthermia, varying concentrations of VMWNPs were stimulated with an $800 \mathrm{~nm}, 1 \mathrm{~W}$ laser for 60 and $120 \mathrm{~s}$ independently. Upon $60 \mathrm{~s}$ of a $1 \mathrm{~W}$ laser exposure to $0,25,50$ and $100 \mu \mathrm{g} / \mathrm{mL}$ NPs, temperature increments of $6.55,10.25$ and $14.85^{\circ} \mathrm{C}$ were obtained, respectively (Supplementary Figure S2a). With a $1 \mathrm{~W}$ laser at $120 \mathrm{~s}$, higher temperatures of $12.45,16.95$ and $22.6{ }^{\circ} \mathrm{C}$ were found (Supplementary Figure S2a). Continuous measurements of temperature increases were recorded with 25, 50 and $100 \mu \mathrm{g} / \mathrm{mL}$ NPs upon $800 \mathrm{~nm}(1 \mathrm{~W})$ laser irradiation for $60 \mathrm{~s}$, further demonstrating that increasing concentrations produce increased temperatures of VMWNPs solutions (Supplementary Figure S2b).

(a)

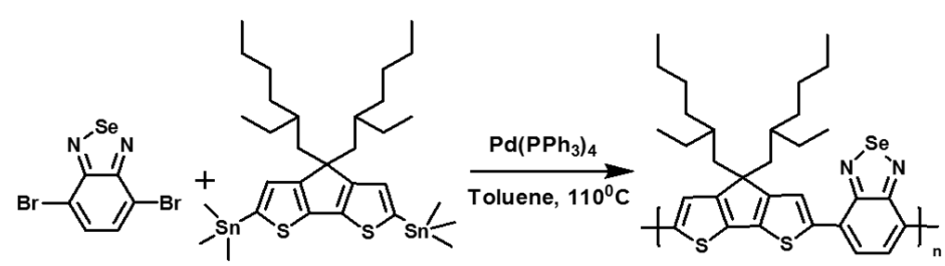

(b)
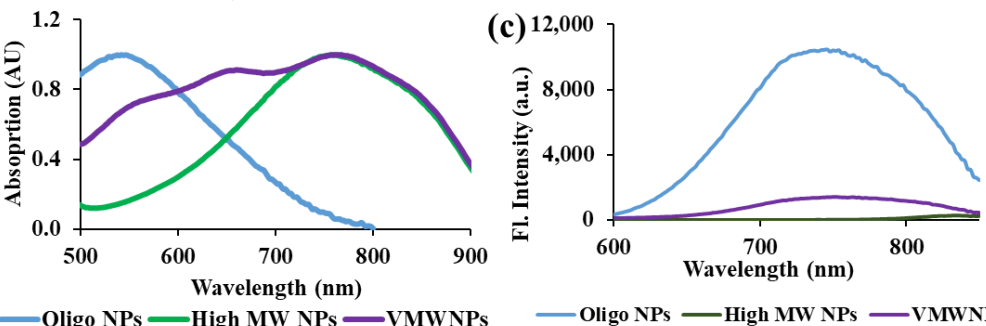

(d)

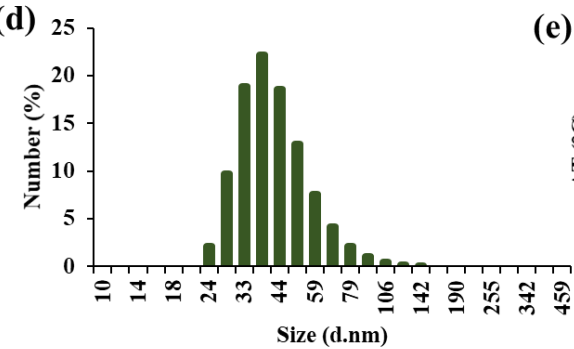

(e)

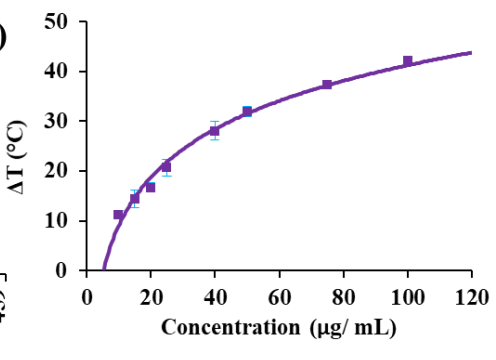

Figure 1. (a) Synthesis of PCPDTBSe by Stille coupling. (b) Absorbance and (c) fluorescence spectrum of oligomer, high MW BSe NPs and VMWNPs. (d) VMWNPs size. (e) Concentration vs. temperature change in VMWNPs with $800 \mathrm{~nm}(3 \mathrm{~W}, 60 \mathrm{~s})$ irradiation.

\subsection{Augmented Response to Oxaliplatin Using Hyperthermia}

Resistance against oxaliplatin was developed by the continuous exposure of oxaliplatin to the parental (OxS) CT-26, HT-29 or RKO cells [29]. To assess how hyperthermia enhanced oxaliplatin efficiency, cells were incubated with oxaliplatin at either $37^{\circ} \mathrm{C}$ or $42{ }^{\circ} \mathrm{C}$ for two hours. Cell death increased with increasing concentrations of oxaliplatin at both temperatures, and a greater loss in viability was noticed at $42{ }^{\circ} \mathrm{C}$ than at $37^{\circ} \mathrm{C}$, most likely due to a higher drug uptake at the elevated temperature. OxS CT-26 cells displayed an insignificant decrease in viability up to $50 \mu \mathrm{M}$ oxaliplatin at $37^{\circ} \mathrm{C}$ and $42^{\circ} \mathrm{C}$. At both 37 and $42{ }^{\circ} \mathrm{C}$, there was a statistically significant reduction in the $\mathrm{OxS}$ population at 100 and $300 \mu \mathrm{M}$ (Figure 2a), although $42{ }^{\circ} \mathrm{C}$ provided a statistical advantage only at $100 \mu \mathrm{M}$. In contrast, OxR CT- 26 cells at $42{ }^{\circ} \mathrm{C}$ provided a statistically significant reduction in viability compared to $37{ }^{\circ} \mathrm{C}$ for all groups except $100 \mu \mathrm{M}$ oxaliplatin. The onset of oxaliplatininduced cell death was not evident until $100 \mu \mathrm{M}$, and a $51 \%$ and $25 \%$ reduction in viability was observed at $300 \mu \mathrm{M}$ at $37^{\circ} \mathrm{C}$ and $42^{\circ} \mathrm{C}$, respectively (Figure $2 \mathrm{~b}$ ). 

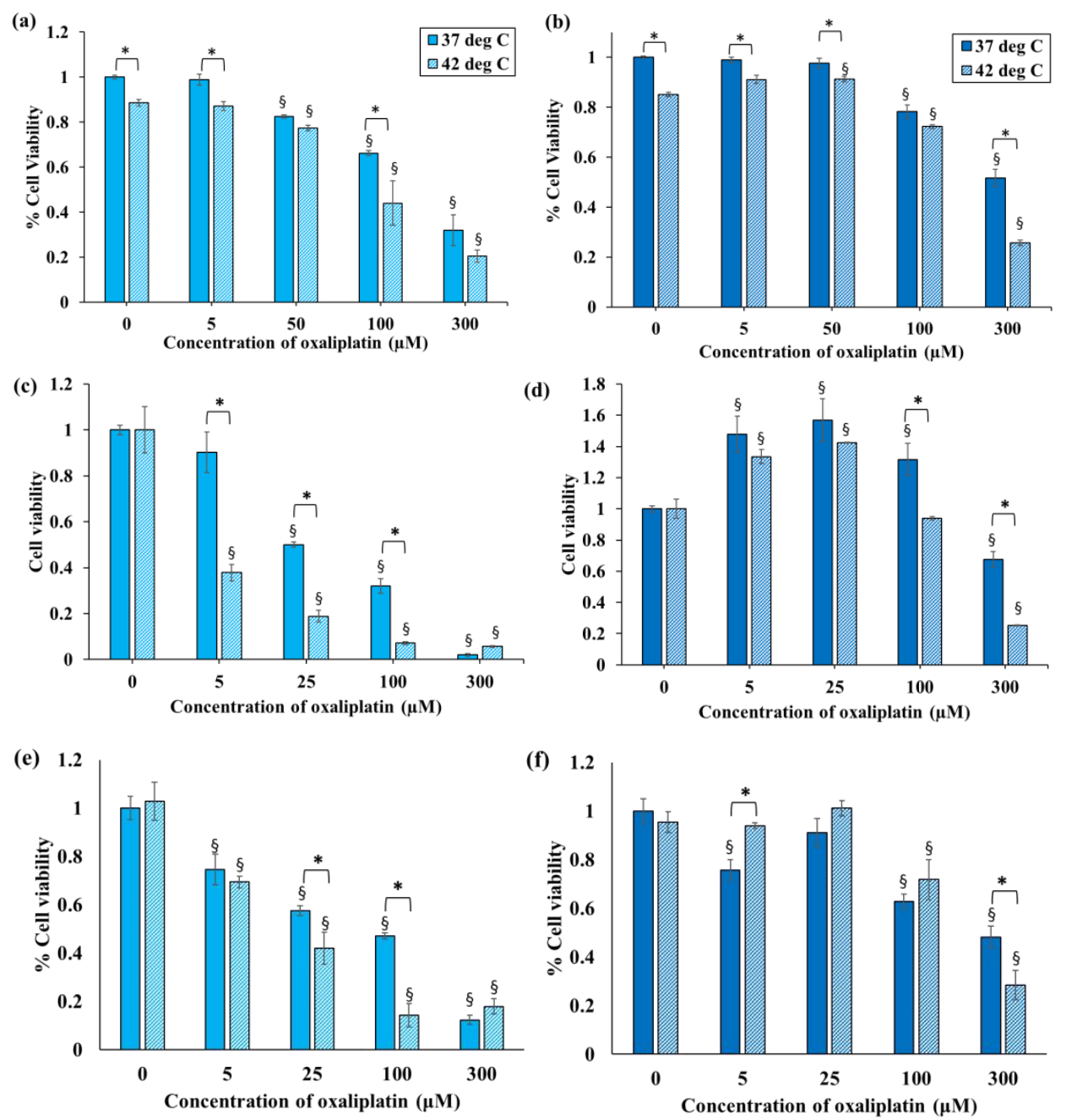

Figure 2. Cell viability with oxaliplatin exposure at 37 or $42{ }^{\circ} \mathrm{C}$, for (a) OxS CT-26, (b) OxR CT-26 cells, or (c) OxS RKO, (d) OxR RKO cells or (e) OxS HT-29, (f) OxR HT-29 cells. § indicates statistical significance compared to the control $\left(0 \mu \mathrm{M}\right.$ oxaliplatin at $\left.37^{\circ} \mathrm{C}\right)(p<0.05) .{ }^{*}$ indicates statistical significance between groups $(p<0.05)$.

OxS RKO cells were reduced at $42{ }^{\circ} \mathrm{C}$ compared to $37^{\circ} \mathrm{C}$ (Figure 2c). In the presence of 25,100 and $300 \mu \mathrm{M}$ oxaliplatin, decreases in cell viability of $50 \%, 68 \%$ and $99 \%$ were found at $37^{\circ} \mathrm{C}$ (Figure 2c). At $42{ }^{\circ} \mathrm{C}, 63 \%, 82 \%, 93 \%$ and $97 \%$, reductions were observed at $5,25,100$ and $300 \mu \mathrm{M}$ oxaliplatin, respectively (Figure 2c). OxR RKO cells had an increased viability for 5, 25 and $100 \mu \mathrm{M}$ at $37^{\circ} \mathrm{C}$, and only had a decrease at $100 \mu \mathrm{M}$ with $42{ }^{\circ} \mathrm{C}$. Only $300 \mu \mathrm{M}$ oxaliplatin resulted in $67 \%$ and $25 \%$ reductions in cell viability at $37{ }^{\circ} \mathrm{C}$ and $42{ }^{\circ} \mathrm{C}$, respectively (Figure 2d). The increase in cell viability for OxR RKO cells at lower oxaliplatin concentrations was an effect that was observed multiple times with this oxaliplatin-resistant cell line. The phenomenon may be described as a hormetic effect, wherein low concentrations of a toxic agent can stimulate cell growth [34-36]. It is an interesting observation that OxR HT-29 cells did not exhibit this effect. This result further supports the mechanisms by which chemotherapy resistance exacerbates CRC recurrence and progression.

OxS HT-29 cells had a decreased viability with an increasing oxaliplatin concentration. Beginning at $5 \mu \mathrm{M}$, there were $25,42,53$ and $88 \%$ reductions with oxaliplatin at $5,25,100$ and $300 \mu \mathrm{M}$ delivered for $2 \mathrm{~h}$ at $37^{\circ} \mathrm{C}$. There were further reductions $(31,58,86$ and $82 \%)$ when oxaliplatin was provided at $42{ }^{\circ} \mathrm{C}$, although mild hyperthermia only provided a statistical advantage at 25 and $100 \mu \mathrm{M}$ oxaliplatin (Figure 2e). These results are in contrast to OxR HT-29 cells, which have a limited reduction in cell viability at 5 and $25 \mu \mathrm{M}$ oxaliplatin 
(Figure 2f). There was a 37 and $52 \%$ reduction in viability for cells treated with 100 or $300 \mu \mathrm{M}$ oxaliplatin at $37^{\circ} \mathrm{C}$. Only $42{ }^{\circ} \mathrm{C}$ and $300 \mu \mathrm{M}$ demonstrated a statistically significant difference compared to OxR HT-29 cells treated at $37^{\circ} \mathrm{C}$, resulting in a $72 \%$ reduction. Mild hyperthermia $\left(42^{\circ} \mathrm{C}\right)$ confers an advantage at lower oxaliplatin concentrations in OxS RKO cells, whereas this effect is only observed at higher concentrations in OxR HT-29 cells. The mouse CT-26 cells and both human RKO and HT-29 cells that were oxaliplatin-resistant demonstrated resistance compared to OxS cells.

\subsection{VMWNPs Cytotoxicity}

The cytotoxicity of VMWNPs against OxS and OxR CT-26, HT-29 or RKO CRC cells for $24 \mathrm{~h}$ is shown in Supplementary Figure S3. VMWNPs produced no considerable cytotoxicity towards OxS and OxR CT-26 cell lines up to a concentration of $100 \mu \mathrm{g} / \mathrm{mL}$ (Supplementary Figure S3a,b). A 39\% and 52\% reduction in cell viability was observed with OxS CT-26 cells at $250 \mu \mathrm{g} / \mathrm{mL}$ and $500 \mu \mathrm{g} / \mathrm{mL}$. A similar phenomenon was observed in OxR CT-26 cells with reductions of $34 \%$ and $50 \%$ with $250 \mu \mathrm{g} / \mathrm{mL}$ and $500 \mu \mathrm{g} / \mathrm{mL}$ of the VMWNPs. OxS RKO cells had a 35\% reduction with 25 and $50 \mu \mathrm{g} / \mathrm{mL}$ of VMWNPs, whereas an $81 \%$ decrease was found with $100 \mu \mathrm{g} / \mathrm{mL}$ NPs (Supplementary Figure S3c). No viable cells were observed at higher concentrations. OxR RKO cells did not show a reduction in cell viability with $25 \mu \mathrm{g} / \mathrm{mL}$ VMWNPs, but showed $26 \%$ and $76 \%$ decreases with 50 and $100 \mu \mathrm{g} / \mathrm{mL}$ NPs (Supplementary Figure S3d). Similar to the OxS RKO cells, no viable cells were detected at higher concentrations. The HT-29 cell response to VMWNPs was more closely aligned with that of CT-26 cells. There was only a significant reduction in viability at $250 \mu \mathrm{g} / \mathrm{mL}$, resulting in 67 and $51 \%$ reductions for OxS and OxR HT-29 cells, respectively (Supplementary Figure S3e,f).

\subsection{Quantification of Singlet Oxygen Generation by VMWNPS}

The generation of singlet oxygen by VMWNPs was monitored using DPBF as a singletoxygen-specific trap. DPBF has a 90 absorption at $418 \mathrm{~nm}$ and, upon reaction with singlet oxygen, loses its absorbance intensity. Therefore, a reduced absorbance of DPBF indicates the generation of singlet oxygen species [37]. No change in absorbance intensity was observed with water or without the laser (Supplementary Figure S4). To evaluate the singlet oxygen generation from VMWNPs, the absorbance intensity of a mixture of DPBF and VMWNPs solutions was monitored in the presence and absence of laser stimulation. As shown in Supplementary Figure S4, the absorption intensity of the solution containing DPBF and VMWNPs was 0.77 , but after three consecutive laser irradiations, the absorption intensity was reduced to 0.24 , whereas in the absence of laser stimulation, the absorbance decreased to 0.61. Nanoparticles composed of oligomeric PCPDTBSe had a reduction of $72 \%$ with laser stimulation, compared to only a $34 \%$ reduction without. VMWNPs had a $64 \%$ reduction with laser stimulation, compared to $21 \%$ reduction without. This indicates that reactive oxygen species stem from the oligomeric fraction of PCPDTBSe. In the absence of laser stimulation, HMWNPs had an absorbance decrease of only $9 \%$, compared to VMWNPs (21\%) and oligomeric NPs (34\%). The generation of reactive oxygen species might be the reason for cytotoxicity of the VMWNPs, as shown in Supplementary Figure S3.

\subsection{Quantification of Intracellular VMWNPS}

The cellular uptake of VMWNPs was quantified with $24 \mathrm{~h}$ of incubation of 25$500 \mu \mathrm{g} / \mathrm{mL}$, delivered in media with or without FBS (without FBS was used to promote cellular uptake by serum starving the cells). Previous literature has demonstrated that serum starving cells, or failing to provide FBS, can further facilitate the uptake of nanoparticles [36,38]. With FBS in the media, OxS CT-26 cells had $0 \mu \mathrm{g} / \mathrm{mL}$ when exposed to 25 or $50 \mu \mathrm{g} / \mathrm{mL}$ of VMWNPs (Supplementary Figure S5a). They had 3, 13 and $17 \mu \mathrm{g} / \mathrm{mL}$ when exposed to 100, 250 or $500 \mu \mathrm{g} / \mathrm{mL}$ of VMWNPs. After OxS CT-26 cells were serum starved, the approximate intracellular concentrations were determined as 4.7, 7.7, 12.7, 
25.9 and $46.1 \mu \mathrm{g} / \mathrm{mL}$ upon incubation with 25, 50, 100, 250 and $500 \mu \mathrm{g} / \mathrm{mL}$ of VMWNPs, respectively. OxR CT-26 cells (Supplementary Figure S5b) have intracellular NPs of 3.8, 2.2, 4.3, 17.7 and $3.8 \mu \mathrm{g} / \mathrm{mL}$ with FBS-containing media, and 1.8, 4.2, 6.5, 13.7 and $18.9 \mu \mathrm{g} / \mathrm{mL}$ for FBS-free media, upon incubation with 25, 50, 100, 250 and $500 \mu \mathrm{g} / \mathrm{mL}$ of VMWNPs, respectively. The absence of FBS appears to drive VMWNP internalization.

As shown in Supplementary Figure S5c, intracellular concentrations for OxS RKO cells treated with 0 up to $100 \mu \mathrm{g} / \mathrm{mL}$ resulted in no measurable intracellular concentration when delivered in FBS-containing media, and 11.6 and $61.3 \mu \mathrm{g} / \mathrm{mL}$ for cells treated with 250 and $500 \mu \mathrm{g} / \mathrm{mL}$. OxS RKO cells treated with VMWNPs in serum-free media had 2.4, 4.2, 6.1, 18.2 and $25.6 \mu \mathrm{g} / \mathrm{mL}$ of intracellular NPs. OxR RKO cells had $0 \mu \mathrm{g} / \mathrm{mL}$ of intracellular VMWNPs regardless of the addition or absence of FBS for 25, 50 and $100 \mu \mathrm{g} / \mathrm{mL}$ (Supplementary Figure S5d). At a dose of $250 \mu \mathrm{g} / \mathrm{mL}$, only serum-starved cells had intracellular VMWNPs, at a concentration of $12.3 \mu \mathrm{g} / \mathrm{mL}$. VMWNPs in FBS-containing media at a concentration of $500 \mu \mathrm{g} / \mathrm{mL}$ had $11.1 \mu \mathrm{g} / \mathrm{mL}$ of intracellular VMWNPs compared to serum-starved cells, which had $32.7 \mu \mathrm{g} / \mathrm{mL}$.

\subsection{Imaging of VMNPS}

OxS and OxR CT-26 cells were serum starved before they were incubated with $100 \mu \mathrm{g} / \mathrm{mL}$ VMWNPs. The in vitro uptake of VMWNPs was visualized through confocal microscopy. Figure 3 shows that red VMWNPs were internalized and visible around the nucleus in OxS and OxR CT-26 cells. Cells without VMWNPs do not exhibit red fluorescence due to the absence of VMWNPs. Interestingly, the OxR CT-26 cells seem to have increased internal VMWNPs, although this observation conflicts with the results of Supplementary Figure S5, which determined that OxS CT-26 cells had a higher intracellular concentration than OxR CT-26 cells. The fluorescence of VMWNPs is also visible in vivo, as demonstrated in Supplementary Figure S6. This figure shows a mouse with no tumor burden and an intraperitoneal delivery of a $100 \mu \mathrm{L}$ volume of $250 \mu \mathrm{g} / \mathrm{mL}$ VMWNPs.

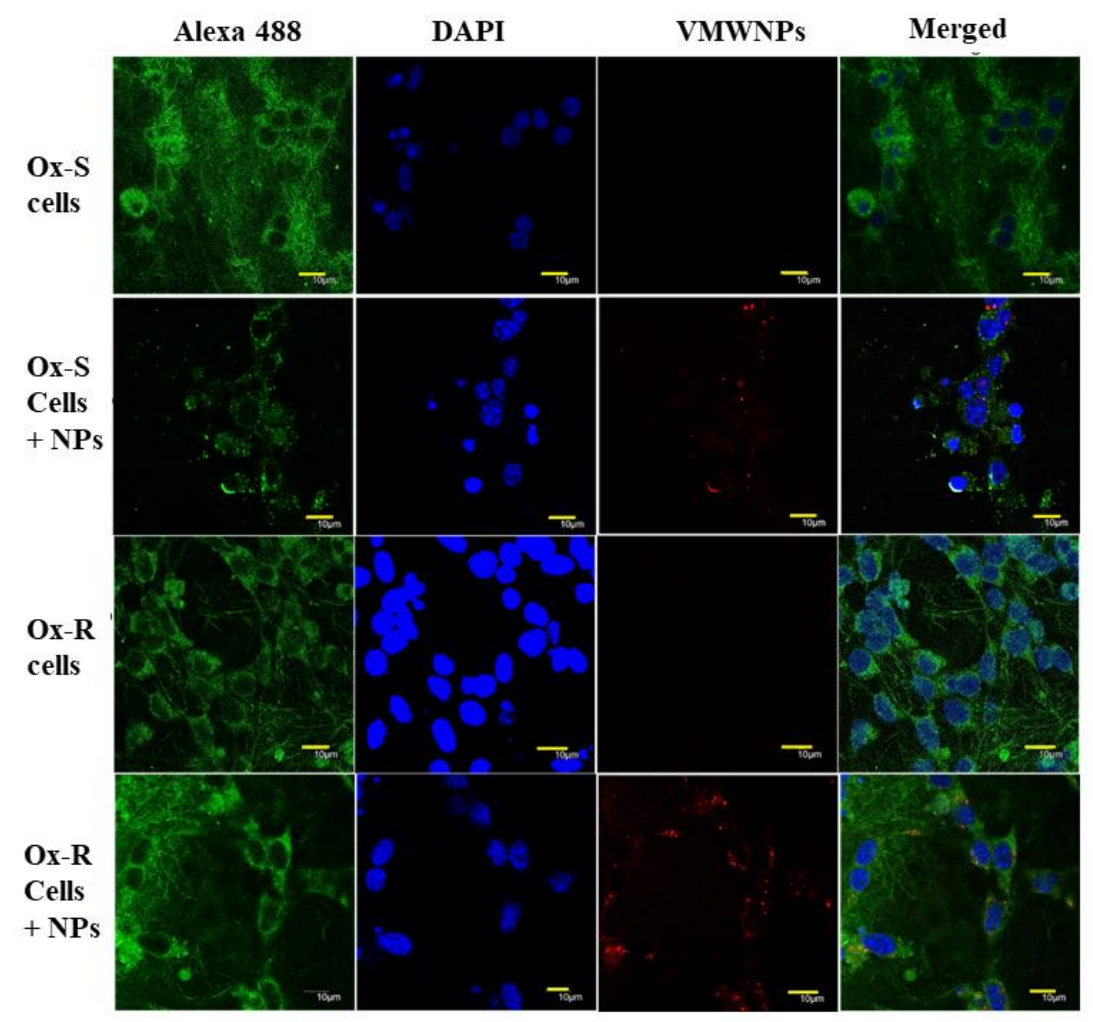

Figure 3. CLSM images of OxS and OxR CT-26 CRC cells with internalization with VMWNPs. Alexa 488 indicates cell cytoskeleton and DAPI indicates the nuclei. 


\subsection{Photothermal Response of Intracellular VMWNPs}

It was estimated that the incubation of $250 \mu \mathrm{g} / \mathrm{mL}$ VMWNPs in CT-26 OxS and OxR might provide sufficient intracellular nanoparticles for photothermal hyperthermia without producing significant cytotoxic effects. From Supplementary Figure S5, this dose provides 25 and $13.7 \mu \mathrm{g} / \mathrm{mL}$ of VMWNPs in OxS and OxR cells, respectively. Therefore, OxS and OxR CT-26 CRC cells were incubated with $250 \mu \mathrm{g} / \mathrm{mL}$ VMWNPs in serum-free media for $24 \mathrm{~h}$. After removing excess nanoparticles, cells were stimulated with an $800 \mathrm{~nm} 3 \mathrm{~W}$ laser for varying times of exposure in order to induce cell ablation. From Figure 1e, $15 \mu \mathrm{g} / \mathrm{mL}$ induced $14{ }^{\circ} \mathrm{C}$ at $60 \mathrm{~s}$ of $3 \mathrm{~W}$ exposure, which is above the $\Delta \mathrm{T}=13^{\circ} \mathrm{C}$ needed for ablation. To help ensure ablation for longer times of laser stimulation, up to $300 \mathrm{~s}$ were used. OxS cells had a reduced viability with VMWNPs and an increasing laser exposure, whereas the laser alone produced no cell death, and actually resulted in a cell stimulation effect, as shown in Supplementary Figure S7a. The increase in cell viability at $240 \mathrm{~s}$ and $300 \mathrm{~s}$ of laser stimulation with internalized VMWNPs may indicate that these cells did not internalize a sufficient concentration of nanoparticles in order to induce photothermal ablation; however, as noted later, internalization of the VMWNPs is not mandatory for inducing sufficient hyperthermia to result in cell death. There were $12.5,76,39$ and $45 \%$ reductions in viable OxS CT-26 cells with 120, 180, 240 and 300 s of laser exposure. Contrary to the OxS CT-26 results, OxR CT-26 cells with internalized VMWNPs exhibited an increase in cell viability both with and without laser exposure. Only at $3 \mathrm{~W}$ for $300 \mathrm{~s}$ was there a profound reduction in viable cells (62\%) (Supplementary Figure S7b).

\subsection{Photothermal Effect of Extracellular VMWNPs}

The photothermal effect of extracellular VMWNPs was evaluated by incubating cells with $0,25,50$ and $100 \mu \mathrm{g} / \mathrm{mL}$ of VMWNPs and immediately exposing them to $800 \mathrm{~nm}$ $(1 \mathrm{~W})$ laser irradiation for $60 \mathrm{~s}$ or $120 \mathrm{~s}$. With $60 \mathrm{~s}$ of laser exposure to the OxS CT-26 cells, there was no significant drop in cell viability up to $50 \mu \mathrm{g} / \mathrm{mL}$, whereas a considerable reduction (52\%) was noticed for $100 \mu \mathrm{g} / \mathrm{mL}$ (Figure 4a). Upon $120 \mathrm{~s}$ of laser stimulation, $50 \mu \mathrm{g} / \mathrm{mL}$ and $100 \mu \mathrm{g} / \mathrm{mL}$ produced almost $92 \%$ and complete ablation, respectively, whereas no effect was observed with the $25 \mu \mathrm{g} / \mathrm{mL}$ of VMWNPs (Figure $4 \mathrm{a}$ ). For the OxR CT-26 cells, $60 \mathrm{~s}$ of laser stimulation resulted in no significant change in cell viability up to $50 \mu \mathrm{g} / \mathrm{mL}$, but produced a $54 \%$ reduction in cell viability at $100 \mu \mathrm{g} / \mathrm{mL}$ (Figure $4 \mathrm{~b}$ ). Two minutes of laser irradiation produced complete ablation with the 50 and $100 \mu \mathrm{g} / \mathrm{mL}$ of VMWNPs, but there was no difference at $25 \mu \mathrm{g} / \mathrm{mL}$ (Figure $4 \mathrm{~b}$ ). For OxS RKO cells, a $68 \%$ decrease in cell viability was observed with $50 \mu \mathrm{g} / \mathrm{mL}$ and complete ablation with $100 \mu \mathrm{g} / \mathrm{mL}$ (Figure 5a), with similar results for 60 or $120 \mathrm{~s}$ exposure. OxS RKO cells had an increase in cell viability with 60 or $120 \mathrm{~s}$ of $1 \mathrm{~W}$ laser stimulation with 0 and $25 \mu \mathrm{g} / \mathrm{mL}$ (Figure 5a). The same trend was observed in OxR RKO cells (Figure 5b). OxR RKO cells treated with $50 \mu \mathrm{g} / \mathrm{mL}$ and immediately exposed to $60 \mathrm{~s}$ of a $1 \mathrm{~W}$ laser had an increased viability, whereas 120 s led to a $22 \%$ reduction. OxR RKO cells treated with $100 \mu \mathrm{g} / \mathrm{mL}$ had $22 \%$ and $82 \%$ reductions for laser exposures of $60 \mathrm{~s}$ and $120 \mathrm{~s}$, respectively. As shown in Figure $5 \mathrm{a}, \mathrm{b}$, control cells that were not exposed to the laser or VMWNPs were included because the human cells indicate that laser stimulation alone promotes an increase in cell viability. This trend was also observed in HT-29 cells, which also have no reduction in viability after $60 \mathrm{~s}$ of laser stimulation plus VMWNPs for OxS HT-29 cells, even up to a concentration of $100 \mu \mathrm{g} / \mathrm{mL}$ (Supplementary Figure S8a). On the contrary, OxR HT-29 cells had a 33\% reduction in viability with $100 \mu \mathrm{g} / \mathrm{mL}$ VMWNPs and $60 \mathrm{~s}$ of laser stimulation (Supplementary Figure S8b). 
(a)

(b)

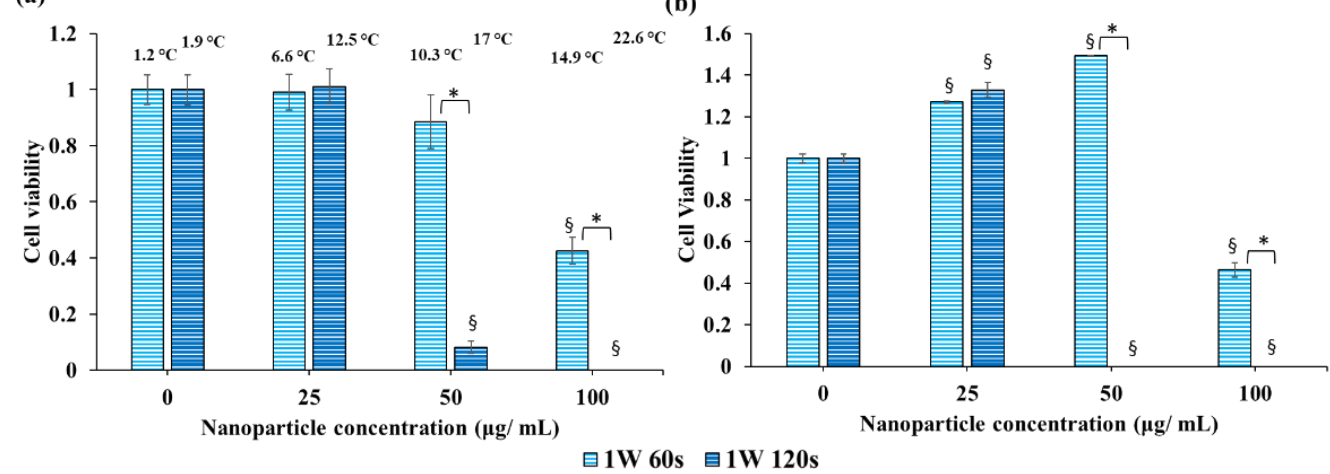

Figure 4. Cell viability of CT-26 cells following photothermal ablation induced by exposure to extracellular VMWNPs, and infrared stimulation for (a) OxS and (b) OxR cells. The values above the columns indicate the maximum temperature change. $\S$ indicates statistical significance compared to the control $(0 \mu \mathrm{g} / \mathrm{mL} \mathrm{VMWNPs})(p<0.05) .{ }^{*}$ Indicates statistical significance between 60 and $120 \mathrm{~s}(p<0.05)$.

(a)

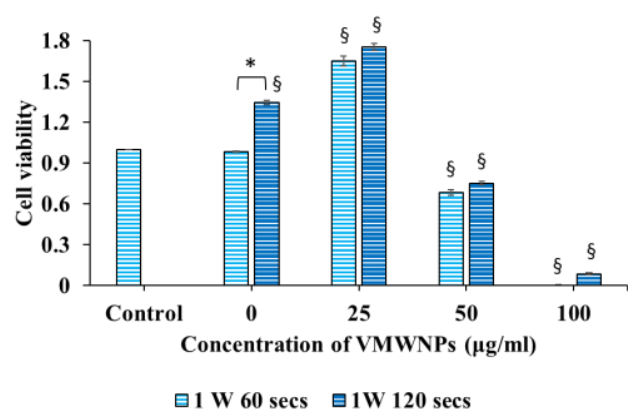

(b)

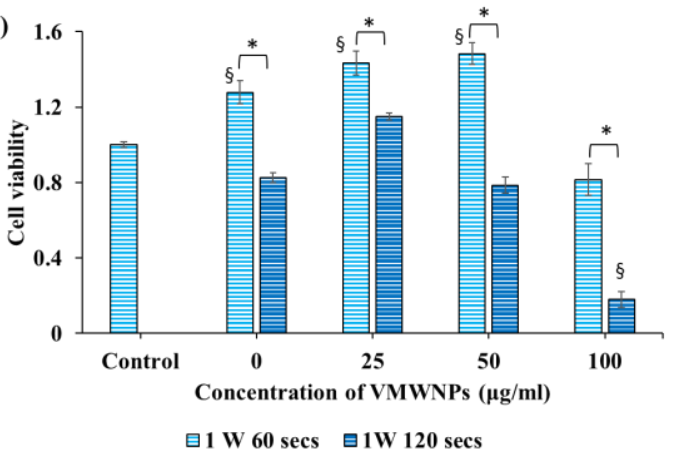

Figure 5. Cell viabilities of (a) parental OxS and (b) resistant OxR RKO CRC cells upon incubation with different concentrations of extracellular VMWNPs followed by $800 \mathrm{~nm}$ laser irradiation $(1 \mathrm{~W}, 60 \mathrm{~s}$ and $1 \mathrm{~W}, 120 \mathrm{~s})$. § indicates statistical significance compared to the control $(0 \mu \mathrm{g} / \mathrm{mL}$ VMWNPs and no laser $)(p<0.05)$. ${ }^{*}$ Indicates statistical significance between 60 and $120 \mathrm{~s}(p<0.05)$.

\subsection{Luminescent Monitoring of Cell Effective Thermal Dose Using VMWNPs}

The thermal dose was measured for OxS and OxR CT-26 CRC cells by measuring the loss of luciferase intensity after the photothermal treatment. An incubation with 0, 25, 50 and $100 \mu \mathrm{g} / \mathrm{mL}$ of VMWNPs followed by $60 \mathrm{~s}$ or $120 \mathrm{~s}$ of $800 \mathrm{~nm}$ laser exposure showed an increasing loss of luminescence in both OxS and OxR CT-26 cells (Figure 6a,b). OxS cells exhibited 35\% and 75\% luminescence loss upon $60 \mathrm{~s}$ and $120 \mathrm{~s}$ of laser stimulation with $25 \mu \mathrm{g} / \mathrm{mL}$, respectively, whereas more than a $90 \%$ luminescence loss was observed at 50 and $100 \mu \mathrm{g} / \mathrm{mL}$ (Figure 6a). OxR cells showed no loss at $25 \mu \mathrm{g} / \mathrm{mL}$ and $60 \mathrm{~s}$ exposure, although a loss of $74 \%$ and $95 \%$ at 50 and $100 \mu \mathrm{g} / \mathrm{mL}$ was observed (Figure $6 \mathrm{~b}$ ). Two minutes of laser excitation depicted a $36 \%$ luminescence loss at $25 \mu \mathrm{g} / \mathrm{mL}$ and a more than $90 \%$ loss for 50 and $100 \mu \mathrm{g} / \mathrm{mL}$. 

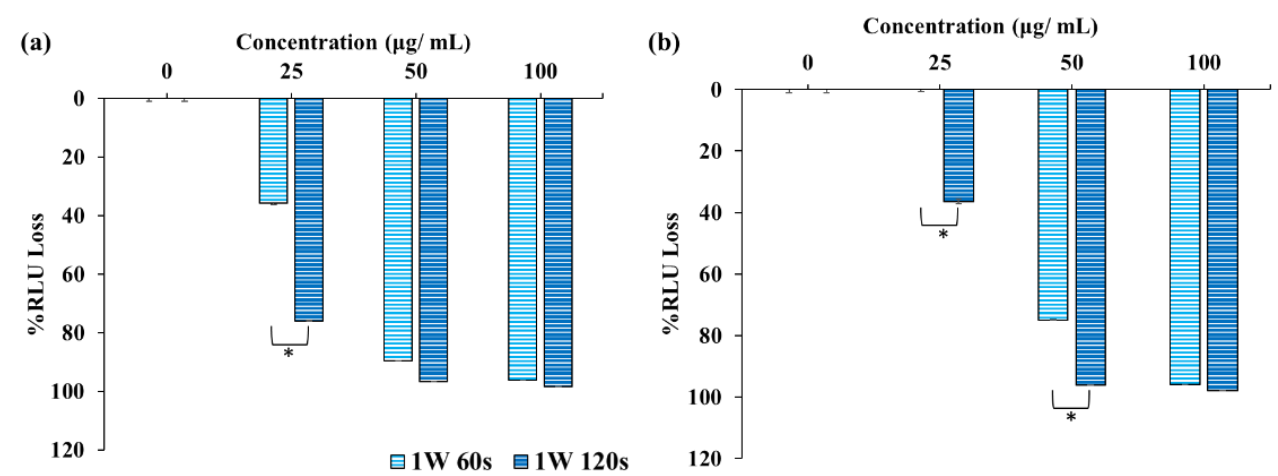

Figure 6. Percent loss of RLU following exposure to increasing VMWNPs concentrations and laser exposure for 60 or $120 \mathrm{~s}$ for (a) OxS and (b) OxR CT-26 cells. * Indicates statistical significance between 60 and $120 \mathrm{~s}(p<0.05)$.

Cumulative equivalent minutes at $43{ }^{\circ} \mathrm{C}$ is a measure of the thermal dose. CEM43 can be calculated using temperature elevations imparted by the VMWNPs. Additionally, CEM43 can be determined by the loss of luminescence following thermal treatments. The calculated value of CEM43 was determined as the sum of CEM43 values calculated at $1 \mathrm{~s}$ intervals. CEM43 values for the cells were determined using the luminescence versus CEM43 standard curve. Figure 7a,b demonstrate that the calculated thermal dose closely matches OxS and OxR cells treated with varying concentrations of VMWNPs and either $60 \mathrm{~s}$ or $120 \mathrm{~s}$ of laser exposure. As observed in cells treated with $100 \mu \mathrm{g} / \mathrm{mL}$, which induces ablative temperatures, there is a loss of correlation between the calculated and experimental CEM43; however, it is well established that the CEM43 model works well with mild hyperthermia and may fail at ablative temperatures [29,32,39].

(a)

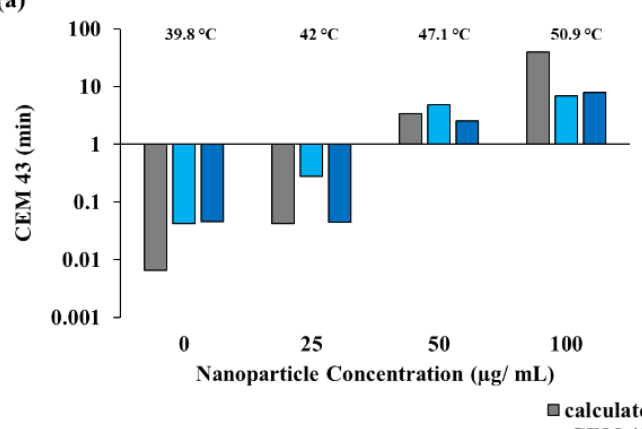

(b)

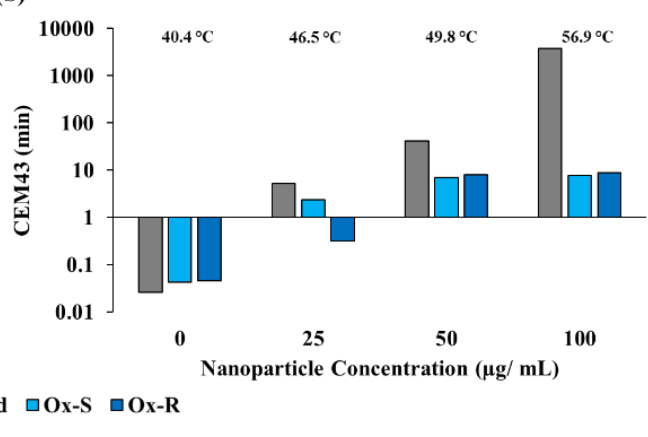

Figure 7. CEM43 versus nanoparticle concentration for OxS and OxR luminescent CT-26 CRC cells exposed to $60 \mathrm{~s}$ (a) or $120 \mathrm{~s}$ (b) of laser stimulation. The numbers above the columns are the maximum temperatures, as determined in Figure S2b.

\subsection{VMWNPs-Induced Hyperthermia for Augmenting Chemotherapy}

The response of hyperthermia-induced drug uptake was evaluated by exposing OxS and OxR cells to oxaliplatin under the conditions: $37^{\circ} \mathrm{C}, 42^{\circ} \mathrm{C}$, laser only, NPs only and 'NPs + laser' groups. As shown in Figure 8a, these treatments produced no decrease in cell viability in the OxS CT-26 cells in the absence of oxaliplatin. There was a reduction in cell viability with increasing concentrations of oxaliplatin observed for all groups. Exposure to $42{ }^{\circ} \mathrm{C}$ for two hours reduced the cell viability compared to the $37^{\circ} \mathrm{C}$, 'NPs only' and 'laser only' groups with increasing concentrations of oxaliplatin. A greater reduction in cell viability was detected upon laser-induced hyperthermia using VMWNPs. The results of VMWNP plus laser, and $42^{\circ} \mathrm{C}$, at 5 and $25 \mu \mathrm{M}$ oxaliplatin, resulted in similar reductions (55 and 70\%, respectively) (Figure 8a). There was no significant difference between $42{ }^{\circ} \mathrm{C}$ and VMWNPs plus laser at $300 \mu \mathrm{M}$; however, the nanoparticles provided a statistically significant advantage in the $100 \mu \mathrm{M}$ group of OxS CT-26 cells. OxS CT-26 cells had decreases 
in viability for all oxaliplatin concentrations, although this trend was only observed for OxR cells treated with 25, 100 and $300 \mu \mathrm{M}$ of oxaliplatin. However, there was an advantage to using $42{ }^{\circ} \mathrm{C}$ with $5 \mu \mathrm{M}$ of oxaliplatin in OxR CT-26 cells, resulting in a $49 \%$ reduction. The VMWNP photothermal treatment used to induce $42{ }^{\circ} \mathrm{C}$ was superior, resulting in an $84 \%$ decrease at $5 \mu \mathrm{M}$ of oxaliplatin. This advantage was not observed at $25 \mu \mathrm{M}$ (Figure $8 \mathrm{~b}$ ). At 100 and $300 \mu \mathrm{M}$ concentrations of oxaliplatin, there was a $98 \%$ and $99 \%$ decrease in viability for the VMWNPs-induced hyperthermia, compared to $87 \%$ and $97 \%$ for $42{ }^{\circ} \mathrm{C}$. There was a statistical advantage of VMWNP hyperthermia at $100 \mu \mathrm{M}$ in both OxS and OxR CT-26 cells, but the benefit was lost at $300 \mu \mathrm{M}$. It was also observed that the laser alone (minimal heat generation because of the absence of VMWNPs) also resulted in decreases in cell viability compared to $42{ }^{\circ} \mathrm{C}$. Figure $8 \mathrm{~b}$ shows the combined effect of chemotherapy and hyperthermia on the OxR CT-26 cells. The resistant cells showed no change in viability with the $37^{\circ} \mathrm{C}, 42^{\circ} \mathrm{C}$, NPs only and 'NPs + laser' groups in the absence of oxaliplatin.
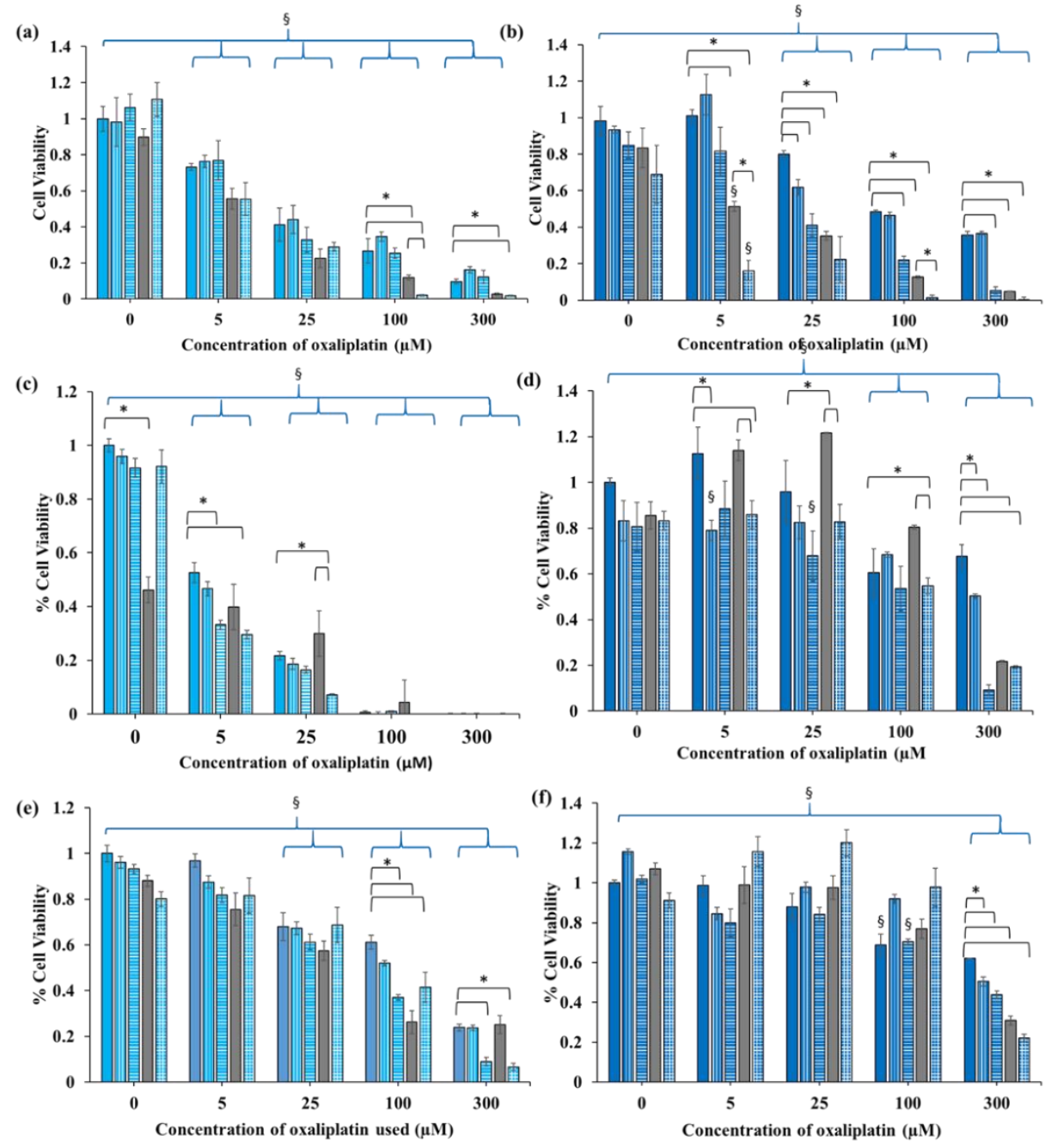

Figure 8. Cell viability of (a) OxS CT-26, (b) OxR CT-26, (c) OxS RKO, (d) OxR RKO, (e) OxS HT-29 and (f) OxR HT-29 cells measured $24 \mathrm{~h}$ after a two hour exposure to increasing concentrations of oxaliplatin and temperatures of 37 or $42{ }^{\circ} \mathrm{C}$ for two hours, compared to $42^{\circ} \mathrm{C}$ induced using laser stimulation of the VMWNPs. * Indicates statistical differences between the groups and $\S$ indicates statistical differences between the treatment group and the untreated control $(p<0.05)$.

The effects of VMWNPs-induced hyperthermia on oxaliplatin efficacy in OxS and OxR RKO cells are provided in Figure 8c,d. Cells were exposed to 0, 5, 25, 100 and $300 \mu \mathrm{M}$ of oxaliplatin at $37^{\circ} \mathrm{C}$, in the presence of NPs, in the presence of an $800 \mathrm{~nm}$ laser $(1 \mathrm{~W}, 60 \mathrm{~s})$, 
at $42{ }^{\circ} \mathrm{C}$ and in NPs + laser treatment groups. In the absence of oxaliplatin, OxS RKO cells showed a $54 \%$ drop in cell viability at $42{ }^{\circ} \mathrm{C}$, but no significant effect was detected with the other treatment groups. OxS RKO cells exhibited statistically significant decreases in viability with increasing oxaliplatin concentrations, and the complete obliteration of cells at 100 and $300 \mu \mathrm{M}$ (Figure 8c). This result is in stark contrast to OxR RKO cells, which only showed sensitivity to 100 and $300 \mu \mathrm{M}$ of oxaliplatin, regardless of the temperature, presence of NPs or photothermal treatment (Figure $8 \mathrm{~d}$ ). The $42{ }^{\circ} \mathrm{C}$ and VMWNPs plus laser groups exhibited almost the same decrease in cell viability ( 81 and $79 \%$ ) at $300 \mu \mathrm{M}$ of oxaliplatin for OxR RKO cells, but the laser stimulation alone also resulted in a substantial reduction.

OxS HT-29 cells begin to be responsive to oxaliplatin at $25 \mu \mathrm{M}$. The use of the laser alone, $42{ }^{\circ} \mathrm{C}$ for $2 \mathrm{~h}$ or $42{ }^{\circ} \mathrm{C}$ induced rapidly using VMWNP photothermal treatment provides a greater decrease in cell viability at 100 and $300 \mu \mathrm{M}$ of oxaliplatin (Figure 8e), although the laser alone once again has benefits and $42{ }^{\circ} \mathrm{C}$ was not beneficial at $300 \mu \mathrm{M}$. OxR HT-29 cells do not have significant reductions until $300 \mu \mathrm{M}$ of oxaliplatin. With $300 \mu \mathrm{M}$ of oxaliplatin, there is a $71 \%$ reduction in cell viability with prolonged heating at $42{ }^{\circ} \mathrm{C}$, compared to a $78 \%$ reduction with VMWNP-induced $42{ }^{\circ} \mathrm{C}$ (Figure 8f). Notably, the human OxR variants are more resistant to oxaliplatin, although hyperthermia at $42{ }^{\circ} \mathrm{C}$ can provide benefits at higher concentrations $(100$ and $300 \mu \mathrm{M})$ of oxaliplatin, with $300 \mu \mathrm{M}$ being a clinically utilized dose [12,17,18,40].

\section{Discussion}

Recently, we have explored the optical properties of different molecular weight fractions of PCPDTBSe and demonstrated the preparation of VMWNPs as a theranostic nanoparticle by combining the NIR emissive oligomer and photothermal high MW fraction. The rapid recombination of electron-hole pairs along the polymer backbone is responsible for heat production from the high MW fraction upon laser stimulation. The aim of combining these two fractions of PCPDTBSe into one nanoparticle was to generate a theranostic material for fluorescence imaging, as well as photothermal therapy, confirmed through the presence of the absorption peaks of the oligomer and high MW PCPDTBSe in the absorbance spectrum of VMWNPs. VMWNPs showed a similar emission spectrum to the oligomer NPs, but with a reduced intensity due to the spectral overlap of the oligomer emission and the high MW absorbance. The VMWNPs manifested photothermal properties, with increasing concentrations sufficient to either ablate cancer cells or induce mild hyperthermia for augmenting chemotherapy. The photothermal conversion efficiency of the VMWNPs was determined to be $46 \%$, which is good for photothermal applications. One of the challenges with theranostic nanoparticles based on polymers that can interface within the nanoparticles is the impact of fluorescence quenching, which drastically reduces the QY $[20,41]$. VMWNPs could be visualized in the peritoneal cavity of a mouse, which is valuable for determining their localization to CRC micrometastases that have disseminated throughout the abdomen. The standard indocyanine green (ICG) filter in the IVIS system allows for the facile detection of VMWNPs. We have previously demonstrated that intravenously delivered polymer nanoparticles can be visualized and the amount localized to a tumor can be quantified using IVIS [20]. ICG is a common fluorescent dye that has been used in angiography and more recently in nanoparticles for the detection and photothermal therapy of tumors. However, ICG does not have a great photothermal conversion efficiency at $15.4 \%$, and free ICG dye has a quantum yield of $2.7 \%$ [42,43]. In addition, ICG and similar fluorescent dyes can photobleach, whereas semiconducting polymers do not [44]. Fluorescence quenching can be overcome by using molecular spacers between the polymer chains so that quenching will be minimized and photothermal efficiency preserved, and this technique has been used to boost ICG nanoparticle fluorescence by up to $16.8 \%$ [45]. Although we did not compare the VMWNPs photothermal performance directly to metal nanoparticles, we have directly compared similar polymer nanoparticles to gold and provided a thoughtful comparative analysis in a recent review article [20,44]. ROS generation by VMWNPs appears to stem from the oligomer fraction, and may lead to cytotoxicity. 
VMWNPs produced no cytotoxicity in CT-26 cells until higher concentrations were reached. On the other hand, both OxS and OxR RKO cells indicated VMWNPs were cytotoxic even at concentrations as low as $100 \mu \mathrm{g} / \mathrm{mL}$. Similar to CT-26 cells, both OxS and OxR HT-29 cells were insensitive to VMWNPs' toxicity at lower doses.

OxS and OxR CT-26 cells showed a greater decrease in cell viability at $42{ }^{\circ} \mathrm{C}$ than at $37^{\circ} \mathrm{C}$ with increasing oxaliplatin concentrations. OxS RKO cells were more susceptible to oxaliplatin than the CT-26 cells. The OxS RKO cells showed a higher cell death at even $100 \mu \mathrm{M}$ of oxaliplatin and a complete cell death with $300 \mu \mathrm{M}$ at $37^{\circ} \mathrm{C}$ and $42{ }^{\circ} \mathrm{C}$. The resistant RKO cells were very resistant to oxaliplatin, with toxicity observed only at 300 $\mu \mathrm{M}$, and hyperthermia seemed to augment this effect. HT-29 cells were not as sensitive to the effects of oxaliplatin, and $42{ }^{\circ} \mathrm{C}$ augmented therapeutic efficacy. OxS HT-29 cells were insensitive to VMWNPs photothermal ablation at $100 \mu \mathrm{g} / \mathrm{mL}$; however, OxR cells were sensitive. Contrarily, OxS RKO cells were highly susceptible to VMWNPs-induced photothermal ablation, although their OxR counterpart was only mildly susceptible. The results indicate that OxS RKO cells may be more sensitive to damage from either thermal or chemical insult compared to the OxR variant.

The effective thermal dose due to VMWNPs-induced photothermal therapy was assessed by correlating the luciferase intensity decreases with increasing concentrations of VMWNPs. The calculated CEM43 fits well with the luminescence loss measurement for low thermal doses in both OxS and OxR CT-26 cells. The goal was to correlate the loss of luminescence for the predictive measurement of decreased cell viability following photothermal treatment. OxS CT-26 cells indicated no loss of viability at a low dose; however, there was RLU loss, which might be indicative of an increased thermal damage that the cells are able to overcome following recovery from photothermal treatment. OxS CT-26 cells treated with 50 and $100 \mu \mathrm{g} / \mathrm{mL}$ and $120 \mathrm{~s}$ of NIR stimulation had profound reductions in viability and corresponding RLU. The RLU reduction at $25 \mu \mathrm{g} / \mathrm{mL}$ for OxR CT-26 cells does not correlate with the lack of reduced cell viability; however, RLU reductions for the 50 and $100 \mu \mathrm{g} / \mathrm{mL}$ at $120 \mathrm{~s}$ of NIR stimulation do. The results of RLU loss are valuable for indicating that sufficient thermally ablative temperatures have been induced, with elevated temperatures leading to $100 \%$ RLU loss immediately after the photothermal treatment and obliteration of viable cells. RLU loss at non-ablative hyperthermia correlates well with calculated values of CEM43. This is a valuable result for nanoparticle-induced hyperthermia because direct intracellular temperatures cannot be measured; however, CEM43 measurements can be correlated with the RLU loss and therefore the intracellular temperature.

Intracellular VMWNPs could easily be identified by their signature red fluorescence, which originates from the oligomeric fraction of PCPDTBSe. We also explored whether intracellular nanoparticles could generate mild hyperthermia or ablation. Laser exposure at higher power and longer times was used to ablate cells, but this only resulted in modest reductions in cell viability. Upon $5 \mathrm{~min}$ of laser exposure, a significant reduction in cell viability was observed with the internalized nanoparticles, whereas no decrease in cell viability was observed in cells without NPs. This proved that the photothermal properties of the VMWNPs remained functional inside cells. In the future, the tuning of the intracellular nanoparticle concentrations could enable the generation of intracellular hyperthermia for the enhanced uptake of chemotherapy drugs. Laser stimulation without VMWNPs increased cell proliferation of both OxS and OxR CT-26 cells. NIR stimulation of OxS CT-26 cells with internalized VMWNPs resulted in significant cell killing at shorter times of laser application; however, this was not observed in OxR CT-26 cells, most likely due to the lower concentrations of internalized NPs. The photothermal ablation results (Figure 4 and Supplementary Figure S6) indicate that (1) internalization of the VMWNPs is not needed for effective treatment, (2) OxR cells might be more susceptible to photothermal ablation techniques that utilize extracellular heating, since they do not internalize as high a concentration as OxS cells, and (3) much higher laser powers and longer times are needed in order to induce the same reduction in cell viability for internalized VMWNPs compared to 
extracellular. This could present a problem, since higher laser powers can induce off-target (non-tumor) thermal injury.

A low concentration $(25 \mu \mathrm{g} / \mathrm{mL})$ of extracellular VMWNPs was found to generate a 5-6 ${ }^{\circ} \mathrm{C}$ increment in temperature upon laser exposure. Our aim was to corroborate whether VMWNPs-induced hyperthermia (which is a rapid technique) was as effective as $42{ }^{\circ} \mathrm{C}$ applied for $2 \mathrm{~h}$ (clinically utilized parameters) for increasing the effectiveness of oxaliplatin against CRC cells that were sensitive or resistant to oxaliplatin. In the absence of oxaliplatin, OxS CT-26 cells with NPs, laser only, NPs and laser or $42{ }^{\circ} \mathrm{C}$ treatments produced minimal reductions in cell viability compared to the control group $\left(37^{\circ} \mathrm{C}\right)$, reflecting no cytotoxic effect of these photothermal treatments. A combination of oxaliplatin with VMWNPs and laser exposure further reduced the cell survival in comparison to cells incubated with oxaliplatin at $42{ }^{\circ} \mathrm{C}$ for two hours. This result indicates that rapid hyperthermia using VMWNPs produces an enhanced chemotherapy outcome compared to heating at $37^{\circ} \mathrm{C}$, and is on par with the results of prolonged heating at $42{ }^{\circ} \mathrm{C}$. One of the fundamental questions regarding hyperthermia is the timing of when it should be applied in order to maximize cancer cell death. Although there is a small therapeutic window in which pre-heating may be beneficial for radiation sensitization, chemotherapy sensitization works best when heat and drugs are combined simultaneously $[46,47]$. There is no advantage of heating cells with mild hyperthermia (below $45^{\circ} \mathrm{C}$ ) to aid in chemo-sensitization [48]. For this reason, clinical treatments use heat plus chemotherapy against colorectal cancer together, most often in the peritoneal cavity, where the application of heat oxaliplatin can be easily deployed [5,49-53].

Due to the drug resistance of OxR CT-26 cells, the reduction in cell viability was not as low as the sensitive cells after the two hours of exposure to oxaliplatin at $42{ }^{\circ} \mathrm{C}$. The addition of VMWNPs followed by laser treatment exhibited a remarkable drop in viability as compared to the $42{ }^{\circ} \mathrm{C}$ treatment. VMWNPs-induced hyperthermia increased the oxaliplatin efficacy irrespective of the oxaliplatin resistance. This hyperthermia effect was achieved by three laser stimulations of a 1 min duration, compared to two hours of hyperthermia at $42{ }^{\circ} \mathrm{C}$. OxS RKO cell lines were found to be very sensitive to oxaliplatin. OxS RKO cells were not only more sensitive to oxaliplatin but also to $42{ }^{\circ} \mathrm{C}$ alone; however, OxR RKO cells showed no profound reduction of cell viability with the treatment groups $\left(37^{\circ} \mathrm{C}\right.$, $42{ }^{\circ} \mathrm{C}$, NPs, laser, and NPs + laser) in the absence of oxaliplatin. Higher concentrations of oxaliplatin enhanced reductions in cell viability in the $42{ }^{\circ} \mathrm{C}$ and 'NPs + laser' group, indicating effectiveness due to hyperthermia. Both OxS and OxR HT-29 cells are more resistant to oxaliplatin compared to CT-26 or RKO cells. They are also not particularly sensitive to $42{ }^{\circ} \mathrm{C}$, provided either by an incubator or VMWNP-induced hyperthermia. However, at higher concentrations of oxaliplatin, VMWNPs conferred an increased reduction in their viability compared to the more prolonged heating at $42{ }^{\circ} \mathrm{C}$. The results demonstrated here provide the first step in demonstrating the safety and efficacy of VMWNPs for the photothermal eradication of CRC. CRC frequently disseminates throughout the peritoneal cavity in small nodules, and although chemotherapy could be suitable for addressing micro-metastasis, the blood-peritoneal perfusion barrier impedes effective chemotherapy. In order to maximize chemotherapy effectiveness, oxaliplatin is often warmed to $42{ }^{\circ} \mathrm{C}$ and perfused throughout the abdomen following surgical debulking to remove larger CRC masses, a technique referred to as heated intraperitoneal chemoperfusion (HIPEC). Our goal here was to demonstrate that VMWNPs could confer an advantage to sensitizing oxaliplatin-resistant CRC. VMWNPs can be perfused throughout the peritoneum to target micrometastases and, upon stimulation with near-infrared light, can generate mild hyperthermia to sensitize the micro-tumors to chemotherapy. Future studies will involve the evaluation of VMWNPs in a murine model of peritoneally disseminated CRC using OxR cells compared to OxS cells, which is similar to our previously established model utilizing fluorescent photothermal nanoparticles for the visualization and treatment of peritoneal carcinomatosis [54]. 


\section{Conclusions}

VMWNPs were utilized for hyperthermia generation to augment chemotherapy in OxS and OxR CRC cells. This treatment technique performed well even with the resistant CRC cell lines. The NIR fluorescence emission of VMWNPs was used to detect their presence inside CRC cells. The ability of intracellular VMWNPs to generate heat for the photothermal ablation of cancer cells was also demonstrated. Increased chemotherapy effectiveness could be imparted by VMWNP-induced hyperthermia $\left(42^{\circ} \mathrm{C}\right)$ with a total of $180 \mathrm{~s}$ of laser exposure, compared to $7200 \mathrm{~s}$ of bulk heating at $42{ }^{\circ} \mathrm{C}$. In conclusion, theranostic VMWNPs were utilized for NIR fluorescence imaging, the quantification of their intracellular uptake, photothermal ablation using both intracellular and extracellular VMWNPs and augmenting chemotherapy against oxaliplatin-sensitive and -resistant CRC cells.

Supplementary Materials: The following are available online at https://www.mdpi.com/article/10 .3390/cancers13174472/s1: Figure S1, zeta potential of VMWNPs; Figure S2, temperature change in solutions; Figure S3, cell viability following VMWNPs exposure; Figure S4, singlet oxygen measurements; Figure S5 intracellular concentrations of VMWNPs; Figure S6, cell viability following exposure to intracellular VMWNPs and laser stimulation; Figure S7, HT-29 response to extracellular VMWNPs photothermal therapy.

Author Contributions: Investigation and analysis, data curation and writing draft-S.S.; conceptualization, supervision, project administration and writing original draft and editing-N.L. Both authors have read and agreed to the published version of the manuscript.

Funding: This work was supported by funding from the Army Grant W81XWH-15-1-0408 and Wake Forest Medical Center's Department of Plastic \& Reconstructive Surgery. The authors wish to acknowledge the support of the Wake Forest Baptist Comprehensive Cancer Center Cell Engineering Shared Resource, supported by the National Cancer Institute's Cancer Center Support Grant award number P30CA012197.

Institutional Review Board Statement: Not applicable, as this work did not utilize human participants or their data, nor did it involve the use of live animals.

Informed Consent Statement: Not applicable, since this work did not involve human participants.

Data Availability Statement: The data presented in this study are available in this article and the Supplementary Materials.

Acknowledgments: We are thankful to Ken Grant, Cellular Imaging Shared Resource at Wake Forest School of Medicine, for help with fluorescence microscopy imaging. We are also thankful to Rong Ma for assistance with cell staining guidance, and to Bryce McCarthy for the development of the oxaliplatin-resistant cells used in this work. Both were members of the Department of Plastic and Reconstructive Surgery at Wake Forest School of Medicine.

Conflicts of Interest: The authors declare no conflict of interest.

\section{References}

1. Kuipers, E.J.; Grady, W.M.; Lieberman, D.; Seufferlein, T.; Sung, J.J.; Boelens, P.G.; Van De Velde, C.J.H.; Watanabe, T. Colorectal cancer. Nat. Rev. Dis. Prim. 2015, 1, 15065. [CrossRef]

2. Bray, F.; Me, J.F.; Soerjomataram, I.; Siegel, R.L.; Torre, L.A.; Jemal, A. Global cancer statistics 2018: GLOBOCAN estimates of incidence and mortality worldwide for 36 cancers in 185 countries. CA Cancer J. Clin. 2018, 68, 394-424. [CrossRef]

3. Street, W. Colorectal Cancer Facts \& Figures 2020-2022; American Cancer Society: Atlanta, GA, USA, 2020; p. 48.

4. Sugarbaker, P.H. Laboratory and clinical basis for hyperthermia as a component of intracavitary chemotherapy. Int. J. Hyperth. 2007, 23, 431-442. [CrossRef]

5. Francescutti, V.; Rivera, L.; Seshadri, M.; Kim, M.; Haslinger, M.; Camoriano, M.; Attwood, K.; Kane, J.M.; Skitzki, J.J. The benefit of intraperitoneal chemotherapy for the treatment of colorectal carcinomatosis. Oncol. Rep. 2013, 30, 35-42. [CrossRef]

6. Verwaal, V.J.; Van Ruth, S.; De Bree, E.; Van Slooten, G.W.; Van Tinteren, H.; Boot, H.; Zoetmulder, F.A. Randomized Trial of Cytoreduction and Hyperthermic Intraperitoneal Chemotherapy Versus Systemic Chemotherapy and Palliative Surgery in Patients With Peritoneal Carcinomatosis of Colorectal Cancer. J. Clin. Oncol. 2003, 21, 3737-3743. [CrossRef] [PubMed] 
7. Ceelen, W.; De Somer, F.; Van Nieuwenhove, Y.; Putte, D.V.; Pattyn, P. Effect of perfusion temperature on glucose and electrolyte transport during hyperthermic intraperitoneal chemoperfusion (HIPEC) with oxaliplatin. Eur. J. Surg. Oncol. 2013, 39, 754-759. [CrossRef]

8. Huang, C.-Q.; Min, Y.; Wang, S.-Y.; Yang, X.-J.; Liu, Y.; Xiong, B.; Yonemura, Y.; Li, Y. Cytoreductive surgery plus hyperthermic intraperitoneal chemotherapy improves survival for peritoneal carcinomatosis from colorectal cancer: A systematic review and meta-analysis of current evidence. Oncotarget 2017, 8, 55657-55683. [CrossRef] [PubMed]

9. Seymour, M.T.; Maughan, T.S.; Ledermann, J.A.; Topham, C.; James, R.; Gwyther, S.J.; Smith, D.B.; Shepherd, S.; Maraveyas, A.; Ferry, D.R.; et al. Different strategies of sequential and combination chemotherapy for patients with poor prognosis advanced colorectal cancer (MRC FOCUS): A randomised controlled trial. Lancet 2007, 370, 143-152. [CrossRef]

10. Hsu, H.-H.; Chen, M.-C.; Baskaran, R.; Lin, Y.-M.; Day, C.H.; Lin, Y.-J.; Tu, C.-C.; Padma, V.V.; Kuo, W.-W.; Huang, C.-Y. Oxaliplatin resistance in colorectal cancer cells is mediated via activation of ABCG2 to alleviate ER stress induced apoptosis. J. Cell. Physiol. 2018, 233, 5458-5467. [CrossRef] [PubMed]

11. Skarkova, V.; Kralova, V.; Vitovcova, B.; Rudolf, E. Selected Aspects of Chemoresistance Mechanisms in Colorectal Carcinoma-A Focus on Epithelial-to-Mesenchymal Transition, Autophagy, and Apoptosis. Cells 2019, 8, 234. [CrossRef]

12. Martinez-Balibrea, E.; Martínez-Cardus, A.; Ginés, A.; de Porras, V.R.; Moutinho, C.; Layos, L.; Manzano, J.L.; Bugés, C.; Bystrup, S.; Esteller, M.; et al. Tumor-Related Molecular Mechanisms of Oxaliplatin Resistance. Mol. Cancer Ther. 2015, 14, $1767-1776$. [CrossRef] [PubMed]

13. Yatvin, M.B. The Influence of Membrane Lipid Composition and Procaine on Hyper-thermic Death of Cells. Int. J. Radiat. Biol. Relat. Stud. Phys. Chem. Med. 1977, 32, 513-521. [CrossRef]

14. Dewhirst, M.W.; Viglianti, B.L.; Lora-Michiels, M.; Hanson, M.; Hoopes, P.J. Basic principles of thermal dosimetry and thermal thresholds for tissue damage from hyperthermia. Int. J. Hyperth. 2003, 19, 267-294. [CrossRef]

15. Van Den Tempel, N.V.; Horsman, M.; Kanaar, R. Improving efficacy of hyperthermia in oncology by exploiting biological mechanisms. Int. J. Hyperth. 2016, 32, 446-454. [CrossRef]

16. Yarmolenko, P.S.; Moon, E.J.; Landon, C.; Manzoor, A.; Hochman, D.W.; Viglianti, B.L.; Dewhirst, M.W. Thresholds for thermal damage to normal tissues: An update. Int. J. Hyperth. 2011, 27, 320-343. [CrossRef] [PubMed]

17. Klaver, C.E.L.; Musters, G.D.; Bemelman, W.A.; Punt, C.J.A.; Verwaal, V.J.; Dijkgraaf, M.G.W.; Aalbers, A.G.J.; van der Bilt, J.D.W.; Boerma, D.; Bremers, A.J.A.; et al. Adjuvant hyperthermic intraperitoneal chemotherapy (HIPEC) in patients with colon cancer at high risk of peritoneal carcinomatosis; the COLOPEC randomized multicentre trial. BMC Cancer 2015, 15, 1-9. [CrossRef]

18. Thomas, F.; Ferron, G.; Gesson-Paute, A.; Hristova, M.; Lochon, I.; Chatelut, E. Increased tissue diffusion of oxaliplatin during laparoscopically assisted versus open heated intraoperative intraperitoneal chemotherapy (HIPEC). Ann. Surg. Oncol. 2008, 15, 3623-3624. [CrossRef]

19. Cao, Z.; Feng, L.; Zhang, G.; Wang, J.; Shen, S.; Li, D.; Yang, X. Semiconducting Polymer-Based Nanoparticles with Strong Absorbance in NIR-II Window for in Vivo Photo-thermal Therapy and Photoacoustic Imaging. Biomaterials 2018, 155, 103-111. [CrossRef] [PubMed]

20. Graham-Gurysh, E.G.; Kelkar, S.; McCabe-Lankford, E.; Kuthirummal, N.; Brown, T.; Kock, N.D.; Mohs, A.M.; Levi-Polyachenko, N. Hybrid Donor-Acceptor Polymer Particles with Amplified Energy Transfer for Detection and On-Demand Treatment of Breast Cancer. ACS Appl. Mater. Interfaces 2018, 10, 7697-7703. [CrossRef] [PubMed]

21. Jiang, Y.; Cui, D.; Fang, Y.; Zhen, X.; Upputuri, P.K.; Pramanik, M.; Ding, D.; Pu, K. Amphiphilic semiconducting polymer as multifunctional nanocarrier for fluorescence/photoacoustic imaging guided chemo-photothermal therapy. Biomaterials 2017, 145, 168-177. [CrossRef]

22. Chen, H.; Zhang, J.; Chang, K.; Men, X.; Fang, X.; Zhou, L.; Li, D.; Gao, D.; Yin, S.; Zhang, X.; et al. Highly absorbing multispectral near-infrared polymer nanoparticles from one conjugated backbone for photoacoustic imaging and photothermal therapy. Biomaterials 2017, 144, 42-52. [CrossRef]

23. Li, D.; Zhang, G.; Xu, W.; Wang, J.; Wang, Y.; Qiu, L.; Ding, J.; Yang, X. Investigating the Effect of Chemical Structure of Semiconducting Polymer Nanoparticle on Photothermal Therapy and Photoacoustic Imaging. Theranostics 2017, 7, 4029-4040. [CrossRef] [PubMed]

24. Lyu, Y.; Fang, Y.; Miao, Q.; Zhen, X.; Ding, D.; Pu, K. Intraparticle Molecular Orbital Engineering of Semiconducting Polymer Nanoparticles as Amplified Theranostics for in Vivo Photoacoustic Imaging and Photothermal Therapy. ACS Nano 2016, 10, 4472-4481. [CrossRef]

25. Sun, H.; Lv, F.; Liu, L.; Gu, Q.; Wang, S. Conjugated Polymer Materials for Photothermal Therapy. Adv. Ther. 2018, 1, 1800057. [CrossRef]

26. Zhang, J. Biocompatible Semiconducting Polymer Nanoparticles as Robust Photoacoustic and Photothermal Agents Revealing the Effects of Chemical Structure on High Photothermal Conversion Efficiency. Biomaterials 2018, 11, 92-102. [CrossRef]

27. Zhen, X.; Xie, C.; Pu, K. Temperature-Correlated Afterglow of a Semiconducting Polymer Nanococktail for Imaging-Guided Photothermal Therapy. Angew. Chem. Int. Ed. 2018, 57, 3938-3942. [CrossRef]

28. Sarkar, S.; Graham-Gurysh, E.G.; MacNeill, C.M.; Kelkar, S.; McCarthy, B.D.; Mohs, A.; Levi-Polyachenko, N. Variable Molecular Weight Nanoparticles for Near-Infrared Fluorescence Imaging and Photothermal Ablation. ACS Appl. Polym. Mater. 2020, 2, 4162-4170. [CrossRef] 
29. McCarthy, B.; Singh, R.; Levi-Polyachenko, N. Oxaliplatin-resistant colorectal cancer models for nanoparticle hyperthermia. Int. J. Hyperth. 2021, 38, 152-164. [CrossRef] [PubMed]

30. Zhu, Z.; Waller, D.; Gaudiana, R.; Morana, M.; Mühlbacher, D.; Scharber, A.M.; Brabec, C.J. Panchromatic Conjugated Polymers Containing Alternating Donor/Acceptor Units for Photovoltaic Applications. Macromolecules 2007, 40, 1981-1986. [CrossRef]

31. Raoof, M.; Zhu, C.; Kaluarachchi, W.D.; Curley, S.A. Luciferase-Based Protein Denaturation Assay for Quantification of Radiofrequency Field-Induced Targeted Hyperthermia: Developing an Intracellular Thermometer. Int. J. Hyperth. 2012, 28, 202-209. [CrossRef]

32. Van Rhoon, G.C. Is CEM43 Still a Relevant Thermal Dose Parameter for Hyperthermia Treatment Monitoring? Int. J. Hyperth. 2016, 32, 50-62. [CrossRef]

33. MacNeill, C.M.; Coffin, R.C.; Carroll, D.L.; Levi-Polyachenko, N.H. Low Band Gap Donor-Acceptor Conjugated Polymer Nanoparticles and their NIR-mediated Thermal Ablation of Cancer Cells. Macromol. Biosci. 2013, 13, 28-34. [CrossRef]

34. Bao, J.; Huang, B.; Zou, L.; Chen, S.; Zhang, C.; Zhang, Y.; Chen, M.; Wan, J.-B.; Su, H.; Wang, Y.; et al. Hormetic Effect of Berberine Attenuates the Anticancer Activity of Chemotherapeutic Agents. PLoS ONE 2015, 10, e0139298. [CrossRef] [PubMed]

35. Iavicoli, I.; Leso, V.; Fontana, L.; Calabrese, E.J. Nanoparticle Exposure and Hormetic Dose-Responses: An Update. Int. J. Mol. Sci. 2018, 19, 805. [CrossRef]

36. Franco, S.; Noureddine, A.; Guo, J.; Keth, J.; Paffett, M.L.; Brinker, C.J.; Serda, R.E. Direct Transfer of Mesoporous Silica Nanoparticles between Macrophages and Cancer Cells. Cancers 2020, 12, 2892. [CrossRef]

37. Rout, B.; Liu, C.-H.; Wu, W.-C. Photosensitizer in lipid nanoparticle: A nano-scaled approach to antibacterial function. Sci. Rep . 2017, 7, 7892. [CrossRef] [PubMed]

38. Xiong, X.; Arvizo, R.R.; Saha, S.; Robertson, D.J.; McMeekin, S.; Bhattacharya, R.; Mukherjee, P. Sensitization of ovarian cancer cells to cisplatin by gold nanoparticles. Oncotarget 2014, 5, 6453-6465. [CrossRef] [PubMed]

39. Pearce, J.A. Comparative analysis of mathematical models of cell death and thermal damage processes. Int. J. Hyperth. 2013, 29, 262-280. [CrossRef]

40. Levi-Polyachenko, N.H.; Merkel, E.J.; Jones, B.T.; Carroll, D.L.; Stewart, I.J.H. Rapid Photothermal Intracellular Drug Delivery Using Multiwalled Carbon Nanotubes. Mol. Pharm. 2009, 6, 1092-1099. [CrossRef] [PubMed]

41. Sen, R.; Singh, S.P.; Johari, P. Strategical Designing of Donor-Acceptor-Donor Based Organic Molecules for Tuning Their Linear Optical Properties. J. Phys. Chem. A 2018, 122, 492-504. [CrossRef]

42. Wang, H.; Li, X.; Tse, B.W.-C.; Yang, H.; Thorling, C.A.; Liu, Y.; Touraud, M.; Chouane, J.B.; Liu, X.; Roberts, M.S.; et al. Indocyanine green-incorporating nanoparticles for cancer theranostics. Theranostics 2018, 8, 1227-1242. [CrossRef] [PubMed]

43. Yang, L.; Zhang, C.; Liu, J.; Huang, F.; Zhang, Y.; Liang, X.-J.; Liu, J. ICG-Conjugated and 125 I-Labeled Polymeric Micelles with High Biosafety for Multimodality Imaging-Guided Photothermal Therapy of Tumors. Adv. Heal. Mater. 2020, 9, 1901616. [CrossRef]

44. Sarkar, S.; Levi-Polyachenko, N. Conjugated polymer nano-systems for hyperthermia, imaging and drug delivery. Adv. Drug Deliv. Rev. 2020, 163, 40-64. [CrossRef]

45. An, F.; Yang, Z.; Zheng, M.; Mei, T.; Deng, G.; Guo, P.; Li, Y.; Sheng, R. Rationally assembled albumin/indocyanine green nanocomplex for enhanced tumor imaging to guide photothermal therapy. J. Nanobiotechnol. 2020, 18, 49. [CrossRef]

46. Issels, R.D. Hyperthermia adds to chemotherapy. Eur. J. Cancer 2008, 44, 2546-2554. [CrossRef]

47. Oei, A.L.; Kok, H.P.; Oei, S.B.; Horsman, M.R.; Stalpers, L.J.A.; Franken, N.A.P.; Crezee, J. Molecular and biological rationale of hyperthermia as radio- and chemosensitizer. Adv. Drug Deliv. Rev. 2020, 163, 84-97. [CrossRef] [PubMed]

48. Makizumi, R.; Yang, W.-L.; Owen, R.P.; Sharma, R.R.; Ravikumar, T.S. Alteration of Drug Sensitivity in Human Colon Cancer Cells after Exposure to Heat: Implications for Liver Metastasis Therapy using RFA and Chemotherapy. Int. J. Clin. Exp. Med. 2008, 1, 117-129. [PubMed]

49. Ahmed, S.; Stewart, J.H.; Shen, P.; Votanopoulos, K.I.; Levine, E.A. Outcomes with cytoreductive surgery and HIPEC for peritoneal metastasis. J. Surg. Oncol. 2014, 110, 575-584. [CrossRef] [PubMed]

50. González-Moreno, S.; González-Bayón, L.A.; Ortega-Pérez, G. Hyperthermic intraperitoneal chemotherapy: Rationale and technique. World J. Gastrointest. Oncol. 2010, 2, 68-75. [CrossRef] [PubMed]

51. Ihemelandu, C.U.; Shen, P.; Stewart, J.H.; Votanopoulos, K.; Levine, E.A. Management of Peritoneal Carcinomatosis From Colorectal Cancer. Semin. Oncol. 2011, 38, 568-575. [CrossRef] [PubMed]

52. Tan, G.; Wong, J. Surgical management and hyperthermic intraperitoneal chemotherapy for locally advanced colorectal cancer. $J$. Gastrointest. Oncol. 2020, 11, 508-512. [CrossRef] [PubMed]

53. Turaga, K.; Levine, E.; Barone, R.; Sticca, R.; Petrelli, N.; Lambert, L.; Nash, G.; Morse, M.; Adbel-Misih, R.; Alexander, H.R.; et al. Consensus Guidelines from The American Society of Peritoneal Surface Malignancies on Standardizing the Delivery of Hyperthermic Intraperitoneal Chemotherapy (HIPEC) in Colorectal Cancer Patients in the United States. Ann. Surg. Oncol. 2014, 21, 1501-1505. [CrossRef] [PubMed]

54. McCabe-Lankford, E.; McCarthy, B.; Berwick, M.A.-P.; Salafian, K.; Galarza-Paez, L.; Sarkar, S.; Sloop, J.; Donati, G.; Brown, A.J.; Levi-Polyachenko, N. Binding of Targeted Semiconducting Photothermal Polymer Nanoparticles for Intraperitoneal Detection and Treatment of Colorectal Cancer. Nanotheranostics 2020, 4, 107-118. [CrossRef] [PubMed] 